Geotechnical Engineering

Volume 165 Issue GE4

Retaining walls in Dublin Boulder Clay, Ireland

Long, Brangan, Menkiti, Looby and Casey
Proceedings of the Institution of Civil Engineers

Geotechnical Engineering 165 August 2012 Issue GE4

Pages 247-266 http://dx.doi.org/10.1680/geng.9.00091

Paper 900091

Received 23/11/2009

Published online 15/05/2012

Keywords: excavation/field testing \& monitoring/retaining walls

ICE Publishing: All rights reserved

\title{
Retaining walls in Dublin Boulder Clay, Ireland
}

1 Michael Long MEngSc, PhD, CEng, MICE, MIEI Senior Lecturer, University College Dublin, Ireland

2. Carl Brangan PhD

Geotechnical Engineer, Applied Ground Engineering Consultants (AGEC) Ltd, Bagenalstown, County Carlow, Ireland
3 Christopher Menkiti MSc, PhD, CEng, MICE Associate Director, Geotechnical Consulting Group, London, UK

4 Michael Looby BAl, MSc

Director, Byrne Looby Partners, Dublin, Ireland

5 Patrick Casey MIEI

Associate, ARUP Consulting Engineers, Dublin, Ireland
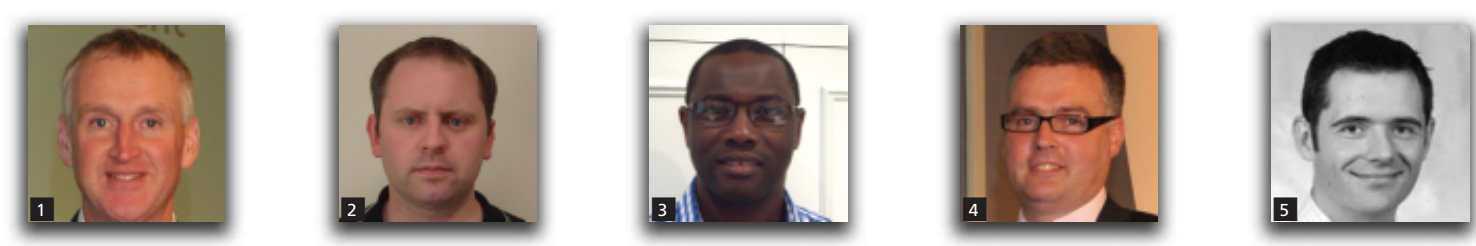

A good number of deep excavations have been recently completed in Dublin Boulder Clay, Ireland. These have included propped walls up to $25 \mathrm{~m}$ deep and permanent cantilevers $7.5 \mathrm{~m}$ high. Experience elsewhere in the world was used to design and construct these walls. However, case history data have shown that the behaviour of the walls in Dublin Boulder Clay is very rigid and much stiffer than comparable systems worldwide. It appears this behaviour is due to the inherent natural strength and stiffness of the soil and the slow dissipation of excavationinduced depressed pore pressures or suctions. There appears to be scope for developing more efficient designs and in particular for reducing propping requirements. For temporary works, the use of undrained parameters in serviceability limit state calculations together with implementation of the observational approach on site could be considered for future schemes.

\section{Introduction}

Over the previous 15 years, economic growth in Ireland has led to an increase in the use of underground space, with some developments now including four underground levels. Valuable full-scale data have been obtained from a good number of these projects. The purpose of this paper is to provide an overview of aspects relating to the design, construction and behaviour of retaining walls in Dublin Boulder Clay. Specifically the paper will

- briefly review the background geology and ground conditions outline the presently used design approach

- review in detail the general behaviour of walls in Dublin Boulder Clay by reference to four case histories namely:

- lightly supported 'regular' wall for $6 \mathrm{~m}$ excavation at Leinster House where pore water and earth pressure changes were measured in additional to regular monitoring

- $7.5 \mathrm{~m}$ excavation for relatively highly stressed anchored wall at Trinity College Library

- $7 \mathrm{~m}$ cantilever wall excavation at Ballycullen Road where monitoring information for some six years is available

- $17.5 \mathrm{~m}$ excavation at the northern cut and cover section of the Dublin Port Tunnel project, which is among the deepest excavations carried out in Dublin to date
- present an overall summary of the behaviour of retaining walls in Dublin Boulder Clay compared to similar support systems worldwide

- provide some overall conclusions and recommendations for the design and construction of future similar schemes.

An exception to the general cover of Dublin Boulder Clay is an area north of the city centre where an old channel of the River Liffey has been infilled with fluvio-glacial sands and gravels. This period has also seen the development of marginal sites, for example areas of Dublin docklands, built on recent filling over soft alluvial soils to reclaim land. These sites previously would have been considered unsuitable for deep basement construction. Issues relating to the design, construction and performance of walls in these two areas are the subject of two separate papers by Long et al. (2012a, 2012b).

\section{Background geology, ground conditions and soil parameters}

Bedrock in the Dublin area is a thin to medium interbedded homogeneous grey argillaceous limestone and calcareous shale. Over much of the city, it is overlain by glacial deposits, known colloquially as Dublin Boulder Clay (DBC), as shown on Figure 1. This is hard lodgement till, which was deposited beneath the ice sheet that covered much of Ireland during the Pleistocene 


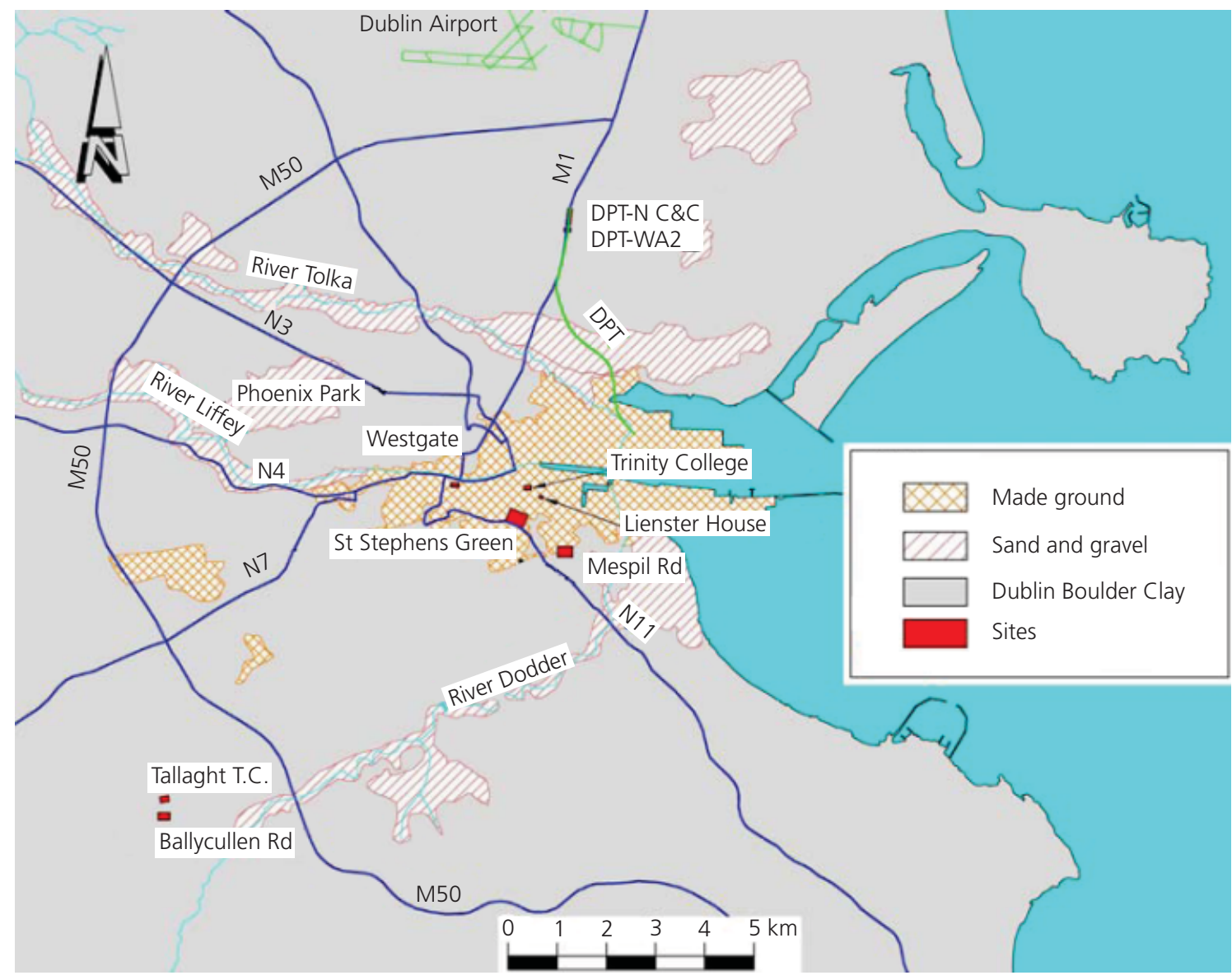

Figure 1. Geology and location of sites

period. It was known that the ice thickness in Dublin was approximately $1 \mathrm{~km}$ and that several advances and retreats of the glaciers occurred in the area. The grinding action of this ice sheet as it eroded the underlying rocks coupled with its loading effect resulted in the formation of a very dense/hard low-permeability deposit, which contains pockets or lenses of coarse gravel.

With the construction of the Dublin Port Tunnel (DPT), a clearer understanding of the detailed geology of these deposits has emerged, see Skipper et al. (2005). These authors identified four distinct formations of the Dublin Boulder Clay, namely the upper brown boulder clay $(\mathrm{UBrBC})$, the upper black boulder clay (UBkBC), the lower brown boulder clay ( $\mathrm{LBrBC}$ ) and the lower black boulder clay (LBkBC). The UBrBC has resulted from oxidation of the clay particles in the top $2-3 \mathrm{~m}$ of the UBkBC, resulting in a change in colour from black to brown and a lower strength material. With the exception of part of the $\mathrm{LBrBC}$, all the units have been interpreted as lodgement tills.

The upper two units have been proven at all investigated sites across the city, see Figure 1, and are the most important from the point of view of retaining walls. Details of the engineering properties and engineering behaviour of DBC have been reported by Long and Menkiti (2007a, 2007b). In summary the material has

- high density $\left(2 \cdot 2-2 \cdot 4 \mathrm{Mg} / \mathrm{m}^{3}\right)$ and relatively high stone content

- low water content (10-13\%) and plasticity index (12-15\%)

generally very low permeability $\left(\approx 10^{-10} \mathrm{~m} / \mathrm{s}\right)$

- very high strength in undrained and effective stress terms $\left(s_{\mathrm{u}}>250 \mathrm{kPa}, \phi^{\prime}>36^{\circ}\right)$ and stiffness $\left(E_{\max }>2000 \mathrm{MPa}\right)$

- a high degree of non-linearity of stiffness

- the tendency to exhibit ductile dilational behaviour under shear.

From the point of view of retaining walls, a particular characteristic of UBkBC is the presence of permeable lenses. In the DPT project these lenses were generally less than $2.0 \mathrm{~m}$ wide and $250 \mathrm{~mm}$ thick (Skipper et al., 2005). They are generally selfdraining within $24 \mathrm{~h}$, suggesting poor interconnectivity. These lenses can have very significant implications for the engineering 
behaviour of the $\mathrm{UBkBC}$, as will be described later. They can, for example, permit rapid dissipation of induced suctions in open steep excavations leading to failures. Also the $\mathrm{LBrBC}$ unit contains more frequent, larger and more complex silt/gravel lenses and cobble lines than the UBkBC. At the DPT site a continuous $2 \mathrm{~m}$ thick layer of silty sand/fine gravel exists within the $\mathrm{LBrBC}$ unit at $10-16 \mathrm{~m}$ depth.

Finally at the DPT site, lensoid rafts of the LBrBC up to $15 \mathrm{~m}$ long were found within the $\mathrm{UBkBC}$, close to its true boundary with the $\mathrm{LBrBC}$. These rafts were slabs of basal material that were detached, transported, redeposited and recompacted within the new lodgement till by the glacier. Occasionally rafts of limestone can also be found within the LBkBC. These are important in ground investigations and design as they can be mistaken for intact bedrock ('false' rockhead).

\section{Design}

Current geotechnical design procedures for retaining walls in Dublin Boulder Clay often involve the following steps.

(a) Following the general guidelines of Gaba et al. (2003) or BS 8002 (BSI, 1994), for ultimate limit state, determine the required retaining wall toe penetration using effective stresses and conventional free earth or fixed earth embedded wall calculations. Safety is introduced in various ways, for example by applying a partial safety factor of 1.3 to the tangent of the effective constant volume friction angle $\left(\phi_{\mathrm{cv}}^{\prime}\right)$. Effective cohesion $\left(c^{\prime}\right)$ is usually assumed to be zero and water pressures are taken as hydrostatic from the groundwater table (typically at about $2 \mathrm{~m}$ ). Calculations are often performed by hand, using conventional Rankine active and passive earth pressure theory, or with the aid of a relatively simple piece of computer software such as Oasys-Stawal ${ }^{\circledR}$, ReWard ${ }^{\circledR}$ or Support-It ${ }^{\circledR}$.

(b) If the retaining wall is required for permanent long-term use, check that this toe penetration is adequate to support any vertical loads and also to prevent significant water seepage.

(c) Determine wall bending moments, shears, prop/waler forces and lateral wall movements (serviceability limit state) by means of a beam-spring computer program such as OasysFrew ${ }^{\circledR}$ (perhaps the most popular choice), Wallap ${ }^{\circledR}$ or ReWard ${ }^{\circledR}$.

(d) As programs such as Frew ${ }^{\circledR}$ are only able to determine wall displacements and not the associated ground movements, these 'green-field' movements are often predicted using empirical based methods, which were developed in the UK and USA, for example by Clough and O'Rourke (1990). These predictions can be adjusted to allow for the effects of the nature of the building and its stiffness if appropriate. Possible building damage is then assessed by comparing predicted building differential settlement, angular rotations or similar, with empirically based tolerable limits, such as those of Burland et al. (1977).

\section{Case history for 'regular' retaining wall - Leinster House}

\subsection{Scheme}

Although the depth of excavation involved at this site is relatively modest, it is of interest owing to its proximity to a number of important historical buildings and the availability of additional data from instruments such as pore pressure sensors and total earth pressure cells. The site location is shown on Figure 1, with the development bounded immediately to the south by Leinster House (with the Senate Room overlooking the site), to the east by the National Gallery of Ireland (but separated from the new building by Dessie's Lane), to the southeast by a sensitive masonry wall referred to as the 'curved wall' and to the west by the former National College of Art and Design (NCAD), which has since been refurbished and is now part of the National Library. This latter structure was potentially the most sensitive of the neighbouring buildings, see Brangan (2007).

Details of the ground conditions, retaining system and monitoring scheme for the NCAD side (west) of the site, are shown on Figure 2. This structure has a masonry structural frame and was particularly sensitive as it is historically important, had relatively inadequate foundations, was in poor condition and its foundations were located within $1 \mathrm{~m}$ of the retaining wall. Before the development, the foundations had been underpinned using conventional mass concrete techniques to $+5.9 \mathrm{~m}$ OD (metres above ordnance datum). Ground conditions are typical for central Dublin. The site is relatively small, being about $45 \mathrm{~m} \times 45 \mathrm{~m}$ in plan area.

\subsection{Construction}

The following construction sequence was adopted.

(a) Clear site to an average of $+7.5 \mathrm{~m}$ OD.

(b) Construct $600 \mathrm{~mm}$ diameter secant piled wall with piles at $500 \mathrm{~mm}$ centres; reinforcement comprised six T25 bars. The piles were not socketed into the rock and the pile toes were at the rock surface at between $-1 \mathrm{~m}$ OD and $-2 \mathrm{~m}$ OD. These piles were constructed using two conventional large-diameter rotary auger rigs within a steel guide. The rigs were $46 \mathrm{t}$ and $63 \mathrm{t}$ in mass and had torque capacity of $120 \mathrm{kN} \mathrm{m}$ and $172 \mathrm{kN} \mathrm{m}$ respectively. Typically four to five piles were constructed per rig per day.

(c) Construct capping beam.

(d) Cantilever excavation to $+4 \mathrm{~m}$ OD. At any one location the wall remained in this state for about 2 weeks.

(e) Insert five universal column (305UC158) raking props, at approximately $45^{\circ}$, in a locally excavated slot (see Figures 2 and 3). Props fixed at base with mass concrete plug and at top to secant wall. Insert cross bracing at seven locations.

$(f)$ Complete excavation to $+1 \cdot 2 \mathrm{~m}$ OD. Excavation blinded immediately on exposure. Again approximately 2 weeks elapsed before the next stage was undertaken. 

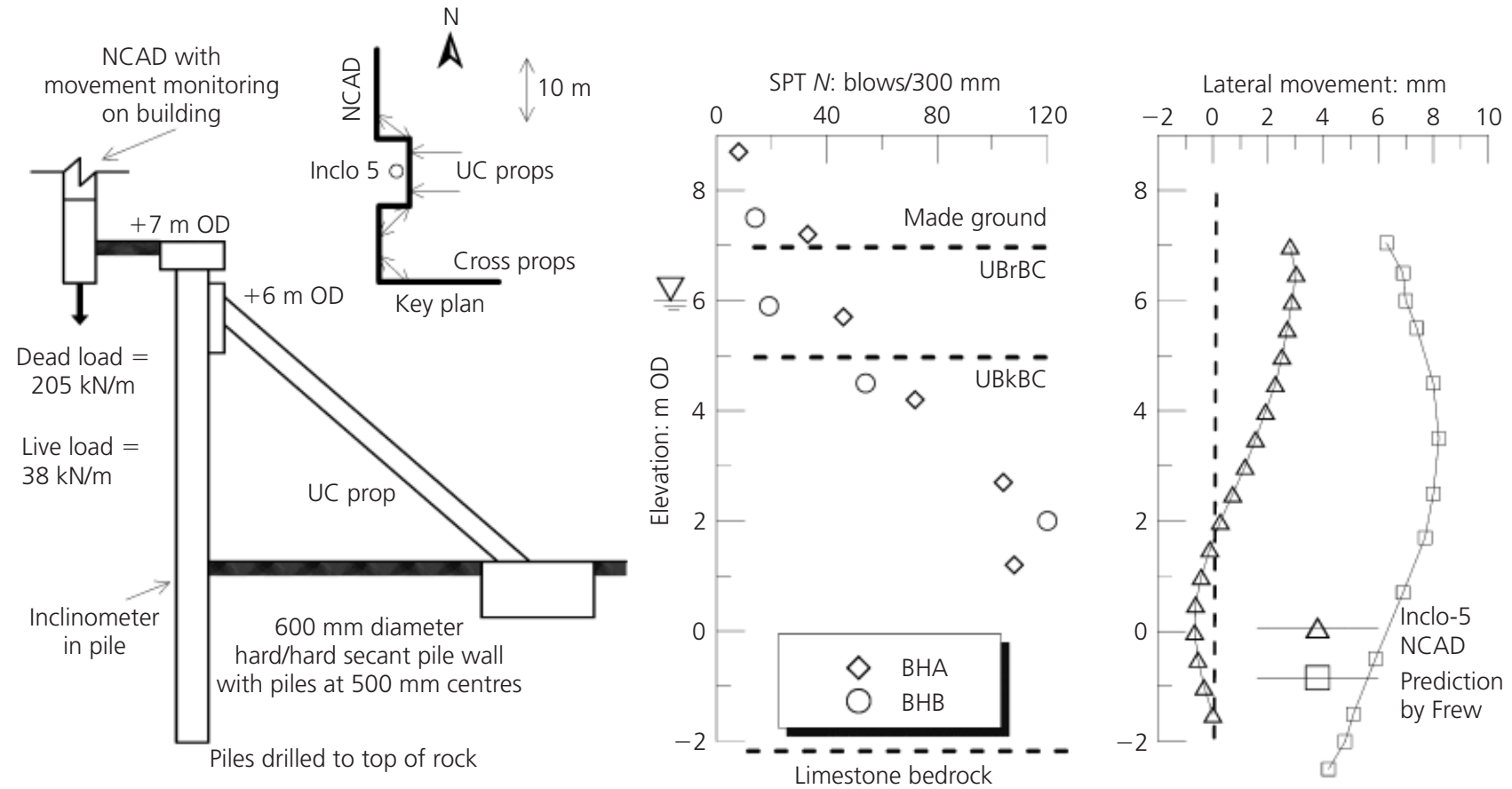

Figure 2. Leinster House: retaining wall layout, ground conditions and lateral wall movements on west side of site (NCAD)
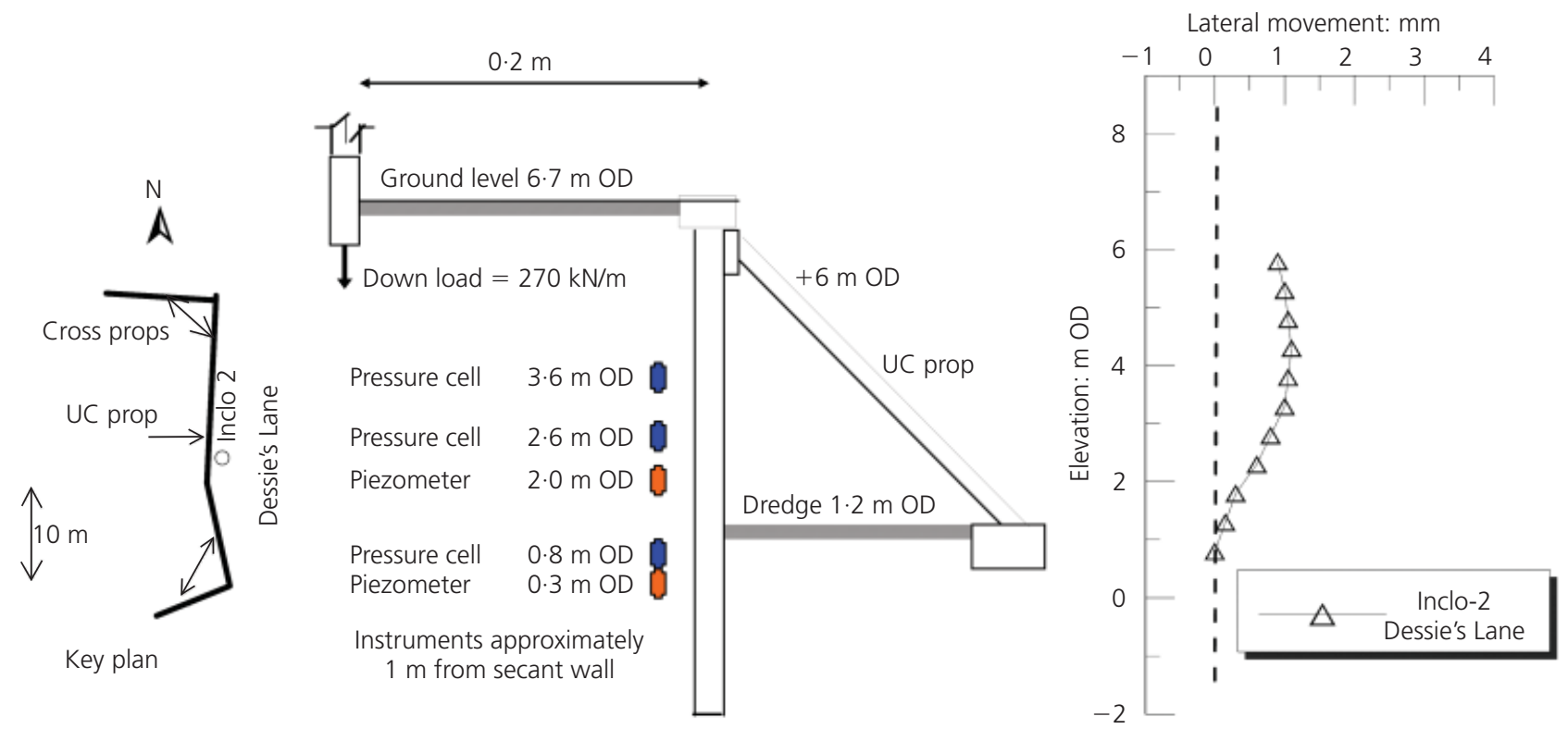

Figure 3. Leinster House: retaining wall layout, location of instruments and lateral wall movements on east side of site (National Gallery)

(g) Construct basement slab and insert vertical ground anchors to prevent long-term uplift. Ground anchors comprised strand anchors installed into the bedrock using rotary percussive techniques with high-pressure air flush.

\subsection{Monitoring}

In addition to conventional techniques for monitoring such as inclinometers (installed in piles only), geodetic surveying using electronic distance measurement (EDM) and surface-mounted 
strain gauges, three vibrating wire piezometers and three total pressure cells were installed approximately $1 \mathrm{~m}$ behind the secant pile wall at the National Gallery (east) side of the site, see Figure 3. As it was not possible to push these instruments into the stony ground, the piezometers were installed in sand and the pressure cells were embedded within a cement-bentonite mix with similar strength and stiffness properties to the boulder clay. This material also formed a seal above and below the piezometers.

\subsection{Monitoring results}

Results of lateral movements of the retaining walls are shown for the NCAD (west) side and the National Gallery (east) sides of the site on Figures 2 and 3 respectively. Overall the movements are very small, being a maximum of $3 \mathrm{~mm}$ and $1 \mathrm{~mm}$ on the west and east sides respectively. Note that the inclinometers were installed within the piles and did not extend below. These values are perhaps on the limits of the measuring accuracy of the equipment. Similarly the EDM measured structure movements varied between 0 and $\pm 3 \mathrm{~mm}$ again at the limits of measuring accuracy. The movement profile at the National Gallery in particular is typical for retaining walls in Dublin Boulder Clay.

Results of monitoring of total earth pressure cells and piezometers are shown on Figures 4(a) and 4(b) respectively. The deepest pressure cell (at $+0.8 \mathrm{~m}$ OD, slightly below formation level) showed a total pressure drop of about $10 \mathrm{kPa}$ in response to total stress release during excavation and a further $5 \mathrm{kPa}$ in the following 2 weeks. It then remained roughly constant until the vertical ground anchors were installed, after which it gradually increased. The highest pressure cell at $+3.6 \mathrm{~m}$ OD gave almost constant readings for the entire monitoring period while that at $+2.6 \mathrm{~m}$ OD gave fluctuating values during the first 5 weeks (possibly due to grout cracking) and then remained relatively constant. These small stress changes are consistent with very small wall movements.

Similarly to the lower pressure cell, both piezometers recorded a drop of about $6 \mathrm{kPa}$ during excavation. This occurred entirely during the second lift of the excavation from $+4.0 \mathrm{~m}$ OD to $+1 \cdot 2 \mathrm{~m}$ OD. Readings remained almost constant until ground anchor construction, when a drop of about $5 \mathrm{kPa}$ was measured. This was possibly due to the effects of air pressures from anchor construction within $10 \mathrm{~m}$ of the wall. Subsequently the readings gradually returned to their original values.

Effective stress changes (calculated from the above) around $+0.5 \mathrm{~m}$ OD and around $+2.3 \mathrm{~m}$ OD are shown on Figure 4(c). At the deeper level there was an approximate $10 \mathrm{kPa}$ drop in effective stress, whereas at the upper level effective stresses increased by about $10 \mathrm{kPa}$ before returning to their original values at the end of the monitoring period.

Attempts were made to monitor prop load using vibrating wire strain gauges. However, temperature effects dominated the read- ings and the actual construction-induced loads were difficult to assess.

\subsection{Comparison with predictions}

A comparison between the measured and predicted movements for the NCAD wall is also shown on Figure 2. These predictions were made by Brangan (2007) using Oasys-Frew ${ }^{\circledR}$ and the undrained soil parameters summarised in Table 1. It can be seen that the predictions are significantly greater than the measured values. Frew ${ }^{\circledR}$ predicts a more curved deflected shape (and hence higher bending moments) than actually occurred. A particular aspect of the predictions is the relatively large movements below the toe of the wall. Brangan (2007) carried out a sensitivity analysis by varying the input parameters. $\mathrm{He}$ found that the output was relatively insensitive to undrained shear strength $s_{\mathrm{u}}$ (once a value greater than about $100 \mathrm{kPa}$ was chosen), $K_{0}$ and wall stiffness. Output was sensitive to choice of undrained Young's modulus, $E_{\mathrm{u}}$, and to prop stiffness.

\subsection{Comment}

The measured stress changes are very small, much smaller than would be predicted using conventional calculations, and are consistent with the observed movements. It is clear that the combination of the high strength and stiffness together with the very low permeability of the boulder clay facilitates the construction of moderately deep basements with little influence on the adjacent ground. This finding is not unlike that in other stiff clays and has resulted in the adoption of the empirically based minimum equivalent fluid pressure (MEFP), approach to give a lower bound pressure limit, see Gaba et al. (2003). Experience in Dublin, reported by Long et al. (2003) would suggest that an excavation, such as that at Leinster House, could have been completed successfully by open cut without any retaining system.

\section{Case history for relatively highly stressed wall - Trinity College Library}

\subsection{Scheme}

The location, shown on Figure 1, was adjacent to the existing Berkeley Library building and combined Arts Building and Lecky Library (to the north and northwest of the new building respectively). Both are relatively modern buildings. The Trinity College playing fields were to the east. The southern edge of the excavation runs parallel to a masonry wall separating the college grounds from Nassau Street, which is a busy thoroughfare linking north and south Dublin (Brangan, 2007).

Although monitoring was carried out by inclinometers at eight locations around the site, the focus here is on the Nassau Street side, where the wall was mostly highly stressed and the greatest movements occurred. Details of the retaining system and ground conditions are shown in Figure 5. Ground conditions comprise fill over medium dense to very dense silty sandy gravel over the Dublin Boulder Clay. Limestone bedrock is at about $-7 \mathrm{~m}$ OD on the Nassau Street side of the site. Although conditions are typical 


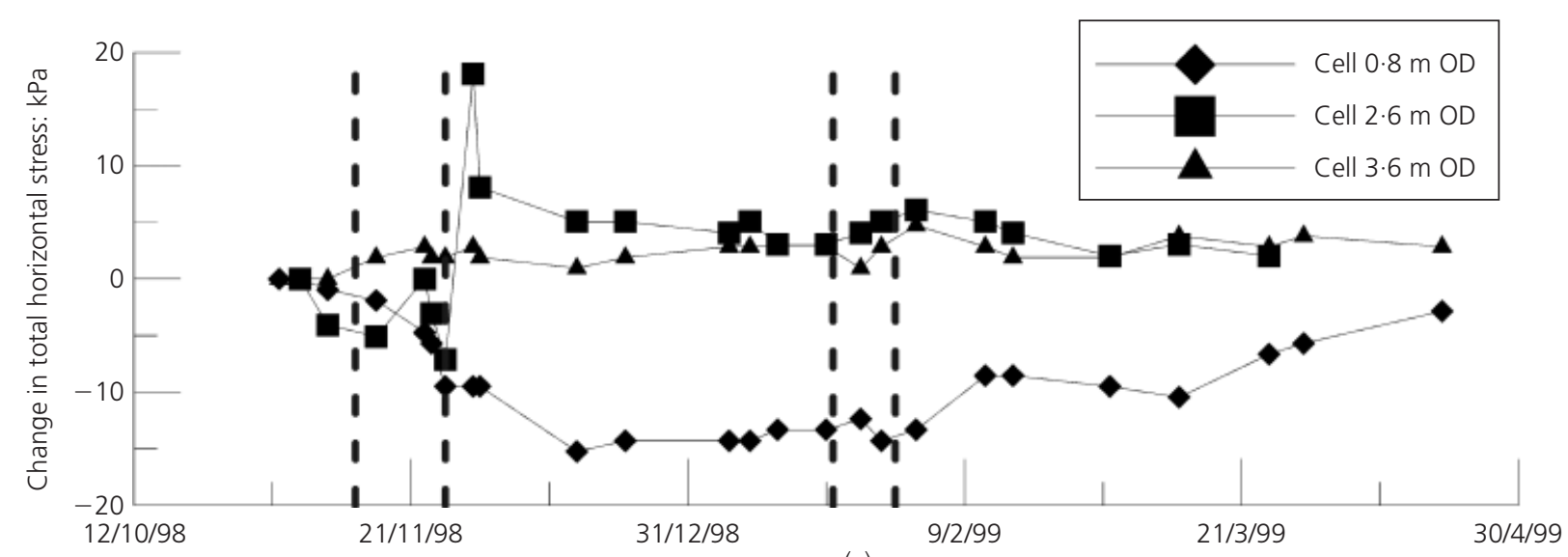

(a)

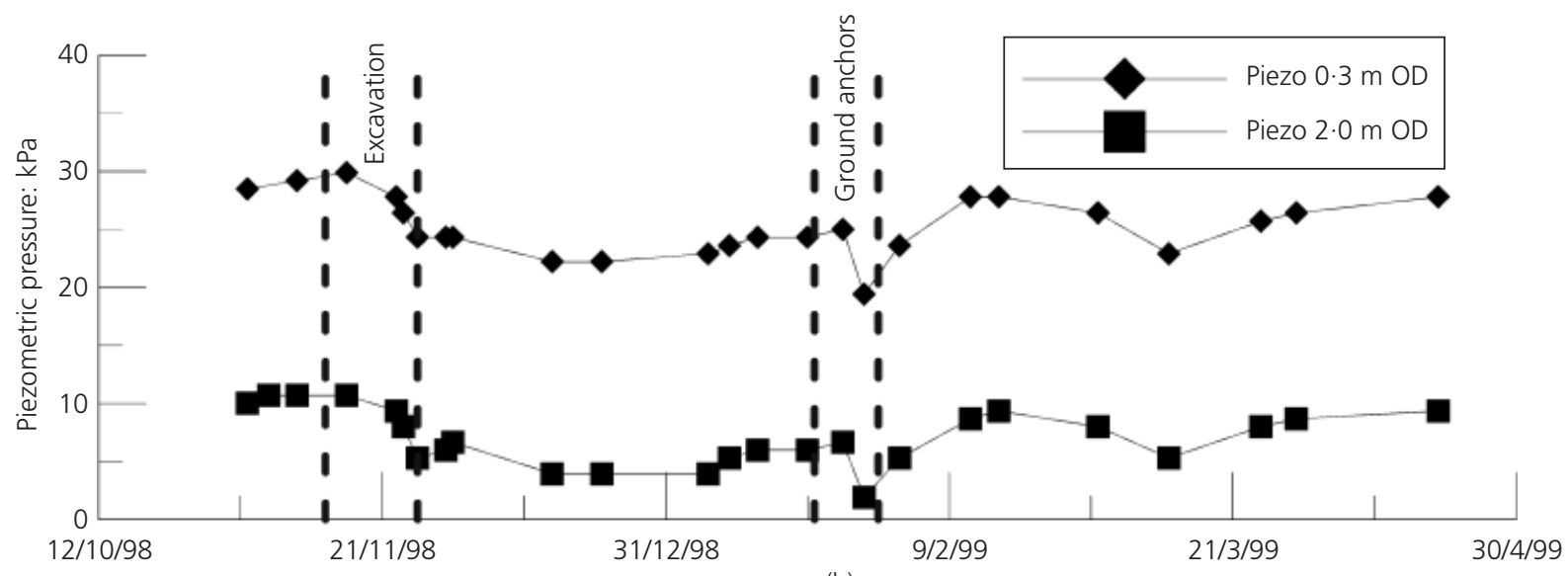

(b)

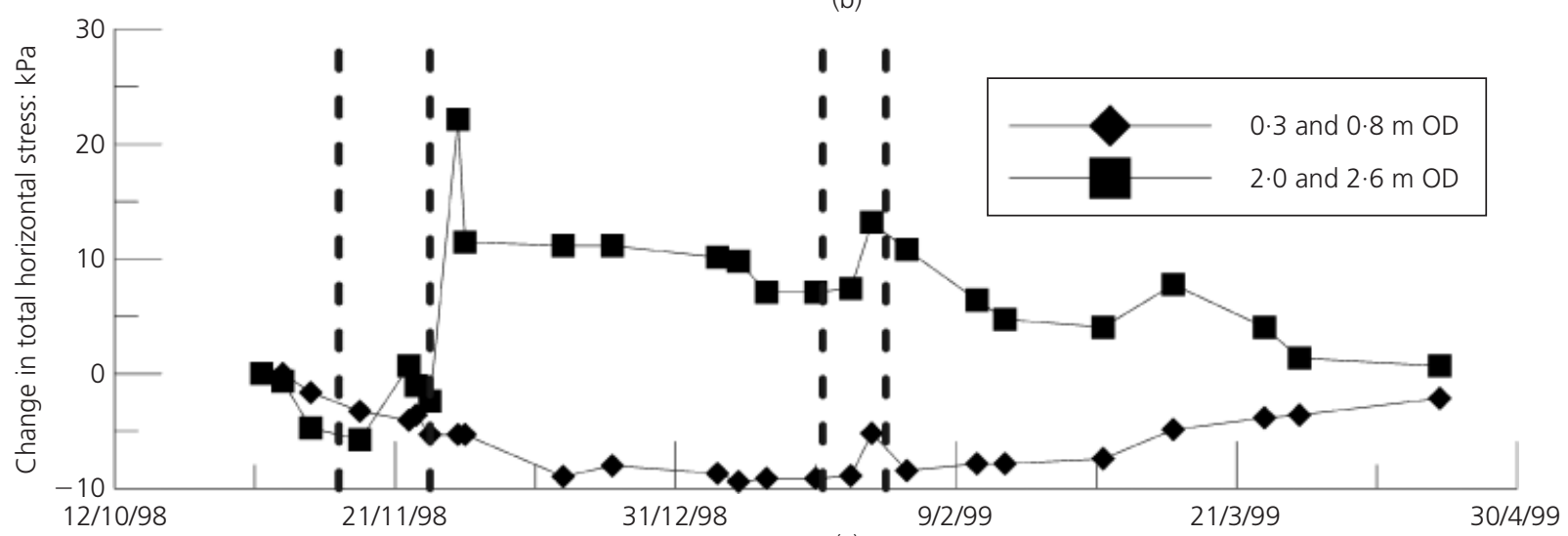

(c)

Figure 4. Leinster House: (a) total earth pressure changes;

(b) piezometric pressures; (c) effective stress changes

for central Dublin, the SPT $N$ values are relatively high, particularly below $+1 \mathrm{~m}$ OD and many refused on cobbles and boulders.

\subsection{Construction}

Along Nassau Street an approximately $9 \mathrm{~m}$ long secant piled retaining wall was used to retain the $7.4 \mathrm{~m}$ deep dig. The piles were $600 \mathrm{~mm}$ in diameter with reinforced piles at $1.1 \mathrm{~m}$ centres with toe level at about $-7 \mathrm{mOD}$. Reinforcement comprised six T25 bars over the full length of the piles. The unreinforced piles comprised lower grade concrete. The piles were constructed using the continuous flight auger (CFA) technique with a $45 \mathrm{t}$ rig which had $60 \mathrm{kN}$ pull-down force and a $100 \mathrm{kN} \mathrm{m}$ torque. This proved inadequate to drill through boulders at approximately $6 \mathrm{~m}$ depth 


\begin{tabular}{|c|c|c|c|c|c|c|c|}
\hline \multirow[t]{2}{*}{ Material } & \multicolumn{2}{|c|}{ General } & \multicolumn{2}{|c|}{ Undrained } & \multicolumn{3}{|c|}{ Drained } \\
\hline & $K_{0}$ & $\gamma: \mathrm{kN} / \mathrm{m}^{3}$ & $E_{\mathrm{u}}: \mathrm{MPa}$ & $S_{u}: k P a$ & $E^{\prime}: \mathrm{MPa}$ & $\phi^{\prime}:$ deg & $C^{\prime}: \mathrm{kPa}$ \\
\hline DBC & $1 \cdot 3$ & $22 \cdot 5$ & $100-120$ & 300 & 80 & 36 & 0 \\
\hline Limestone & 1.0 & 25 & 1000 & 500 & 800 & 45 & 0 \\
\hline
\end{tabular}

Note: $K_{0}=$ coefficient of earth pressure at rest, $\gamma=$ unit weight, $E_{\mathrm{u}} / E^{\prime}=$ undrained/drained Young's modulus, $s_{\mathrm{u}}=$ undrained shear strength, $\phi^{\prime}=$ effective friction angle, $c^{\prime}=$ effective cohesion.

Table 1. Summary of retaining wall analysis input parameters

and had to be supplemented with eccentric overburden (ODEX) drilling using a $640 \mathrm{~mm}$ drill, which readily dealt with the boulders encountered. No rock sockets were constructed. Overall progress of the piling work varied between 10 and 15 piles per day. Overbreak was not significant and never greater than $5-$ $10 \%$.

As can be seen on Figure 5, two rows of anchors, at about $+1.8 \mathrm{~m}$ $\mathrm{OD}$ and $-2 \mathrm{~m}$ OD and at 3-6 $\mathrm{m}$ centres, were used to prop the wall on the Nassau Street side. A small prestress, imposed by manual tightening, was applied to the anchors.

Basement construction took approximately 6 months with up to 2 months being required to install ground anchors at a particular level. Otherwise excavation proceeded as rapidly as allowed by conventional plant and the formation was blinded immediately on exposure.

\subsection{Monitoring results}

Several of the inclinometer tubes did not extend as far as the dredge level as it proved difficult to get them into the CFA piles. Lateral movements and wall bending were considerably greater along the Nassau Street side of the site than elsewhere, see Figure 5. This was because significant surcharge existed along Nassau Street due to the presence of the busy road. In addition, sumps located beside inclinometer Nassau 2 locally increased the dig level to $-6.8 \mathrm{~m}$ OD. At least $7 \mathrm{~mm}$ of displacement was recorded in both inclinometers, although $12 \mathrm{~mm}$ or more relative movement may be inferred from the shape of the profile at Nassau 2. The profiles shown in Figure 5 are the maximum observed

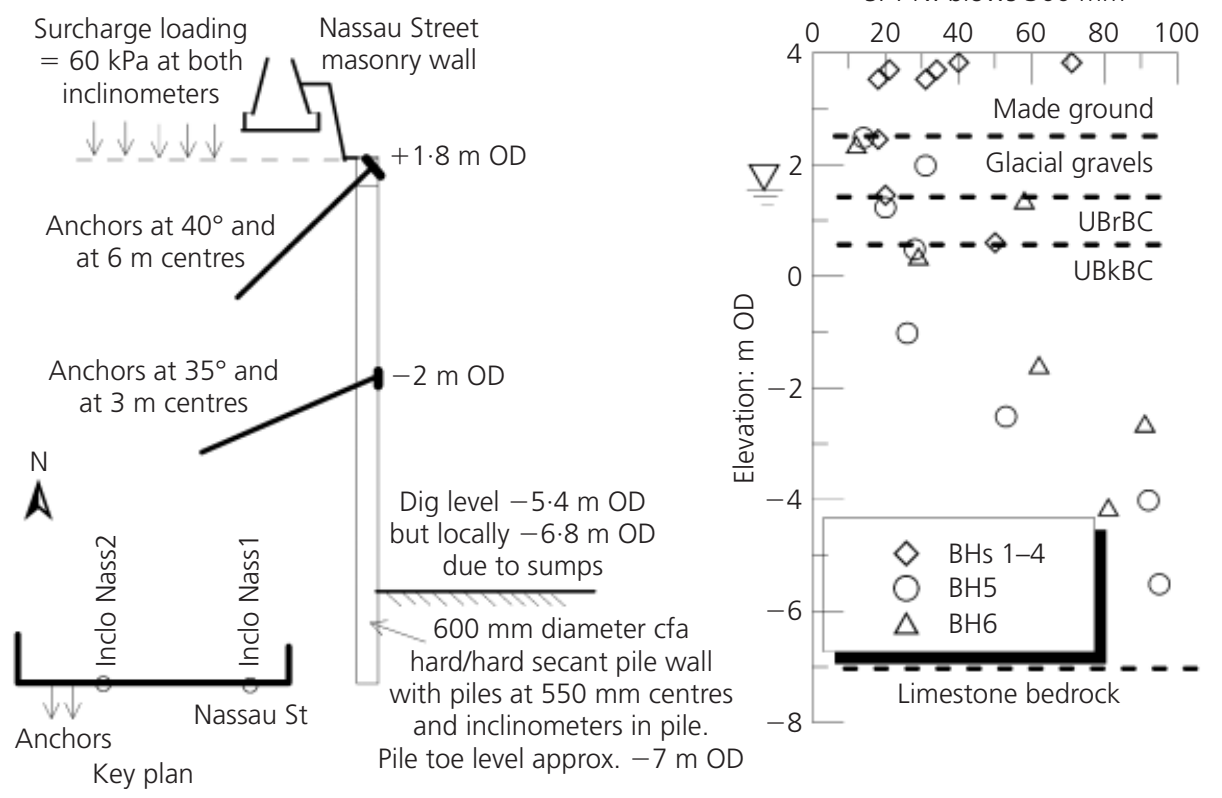

SPT $N$ : blows $300 \mathrm{~mm}$

Key plan

Dig level $-5.4 \mathrm{~m}$ OD

ut locally $-6 \cdot 8 \mathrm{~m}$ OD

$600 \mathrm{~mm}$ diameter cfa hard/hard secant pile wall with piles at $550 \mathrm{~mm}$ centres and inclinometers in pile.

Figure 5. Trinity College Library: retaining wall layout, ground conditions and lateral wall movements on south side of site (Nassau Street)

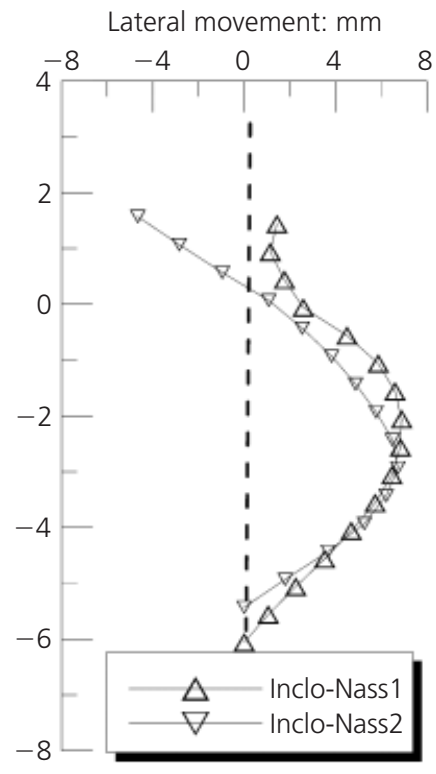


movement. It was observed that up to $2 \mathrm{~mm}$ of the lateral movement occurred during the period after the final excavation and before the construction of the basement slab. After basement slab construction no additional movement was observed.

\subsection{Comment}

Here again the measured movements were significantly less than those predicted using conventional techniques, see Brangan (2007). Despite the relatively high load on the wall and the lack of a significant pile penetration below dig level, the recorded movements are again relatively modest. Once again the inherent properties of the boulder clay permit relatively deep excavation without significant strains being developed.

\section{Results for a 7-5 m cantilever wall - Ballycullen Road}

Case histories similar to those described above have increased design engineers' confidence in the ability of the Dublin Boulder Clay to sustain relatively large excavation-induced loading with little support. Hence cantilever walls are now being constructed for excavation depths of up to $8 \mathrm{~m}$. Mostly, these walls are for temporary works purposes with a design life of 6 months or less. However, there are some examples of such walls being used in the permanent condition, for example that at Ballycullen Road, for which the design life is 50 years

\subsection{Scheme}

This project was a residential development located at Hunters Wood, Ballycullen Road in the Knocklyon area of Dublin, see Figure 1, and is described in more detail by Looby and Long
(2007). An outline of the scheme, together with the ground conditions and recorded lateral wall movements, are shown on Figure 6. Ground level is at about $+107 \mathrm{~m}$ OD and ground conditions at the site consisted predominantly of glacial till. SPT $N$ values were very variable, but were generally consistent with competent very stiff to hard boulder clay. Groundwater was encountered at the interface of the UBrBC and UBkBC

Effective stress design parameters, as summarised in Table 1, were used for the long-term ultimate limit state design analyses. Groundwater pressures were determined from simple seepage calculations. No non-pure two-dimensional cantilever effects were assumed in the design and the relieving slab was assumed to act as a simple prop only. Undrained soil parameters, again summarised in Table 1, were used for the serviceability limit state calculations. Predicted pile deflections were $40 \mathrm{~mm}$ and $45 \mathrm{~mm}$ respectively in the temporary and permanent conditions.

The retaining wall comprised a $600 \mathrm{~mm}$ diameter contiguous pile wall with piles at $750 \mathrm{~mm}$ centres. Pile length varied between $9 \mathrm{~m}$ for a $4.4 \mathrm{~m}$ permanent cantilever and $14 \mathrm{~m}$ for a $6.3 \mathrm{~m}$ permanent cantilever. The piles are reinforced over their full length with eight $\mathrm{T} 32$ reinforcing bars. Although cantilever height varied, the entire wall was designed to span $7.5 \mathrm{~m}$ during construction. In the long term a basement concrete slab provided a low-level prop/restraint and reduced the effective cantilever height to some $6.5 \mathrm{~m}$, see Figure 6 . This slab was not structurally fixed to the piles and acted as a simple prop only.

The methodology of construction was to follow the observational
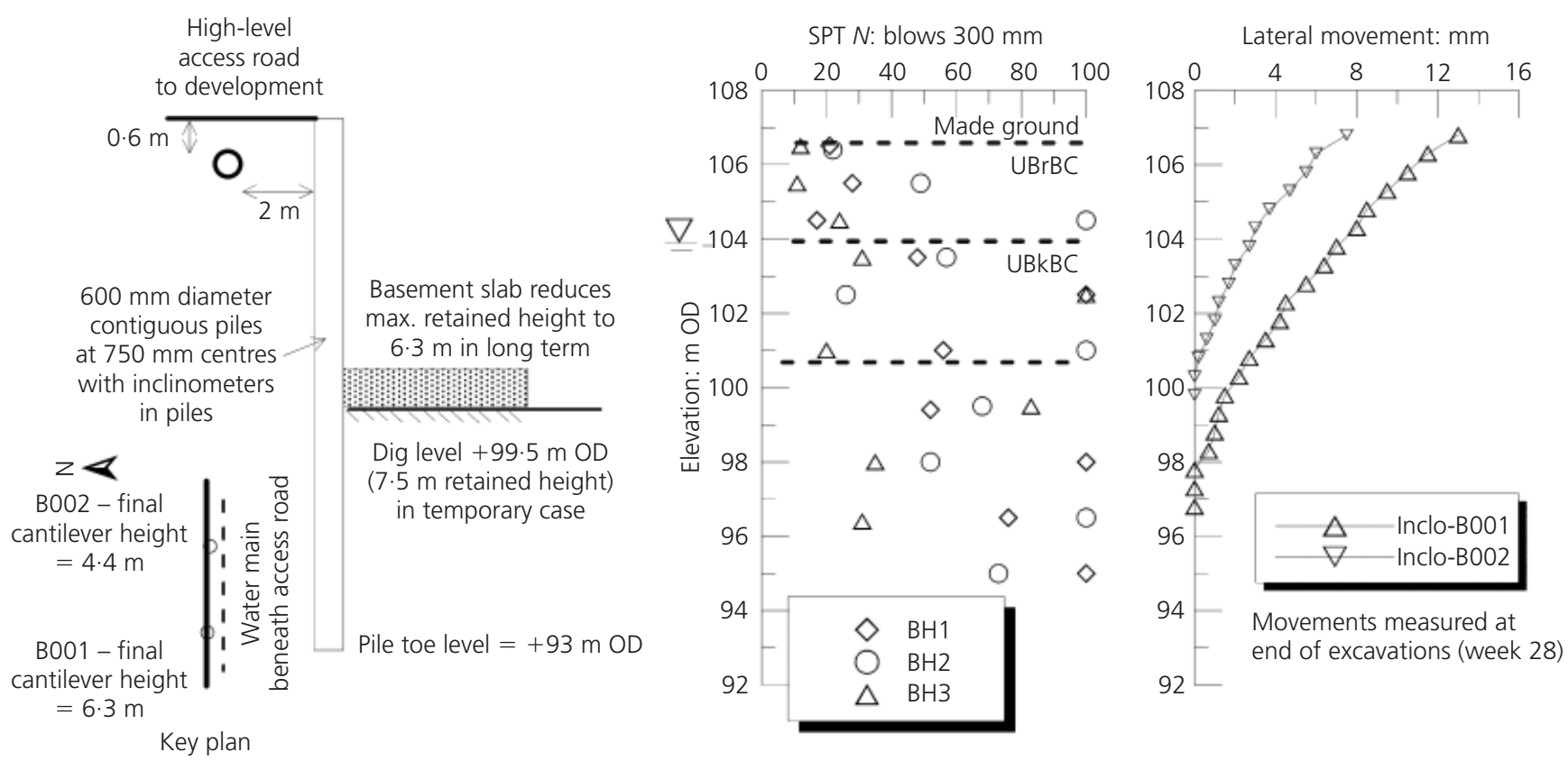

Figure 6. Ballycullen Road: retaining wall layout, ground conditions and lateral wall movements at end of excavation 
approach as documented by Nicholson et al. (1999). As a result, before commencement of construction a number of design, construction and performance criteria (including contingency measures) were established, including the following.

- If local gravel layers were encountered they would be shotcreted to prevent loss of ground between piles.

- If more significant gravel layers were encountered a secant pile wall solution would be installed.

- If movement levels in the construction stage exceeded a trigger level of $25 \mathrm{~mm}$, tie-back anchors would be installed. These construction stage trigger values were selected to ensure that subsequent deflections over the design life would not be excessive. The main objective was to avoid damage to the adjacent road and water pipe. Wayleaves for anchor construction had been negotiated prior to the works. The piling contractor was in a position to commence installation of ground anchors within $12 \mathrm{~h}$.

\subsection{Construction}

The retaining wall was constructed using the continuous flight auger (CFA) technique with an $85 \mathrm{t}, 250 \mathrm{kN} \mathrm{m}$ torque rig, which has a pull-down force of $100 \mathrm{kN}$. Typically $15-20$ revolutions/ min were required to progress the drilling and it took about 20 min to drill the full pile length. Overall progress of the piling work varied between ten and 15 piles per day and no difficulties were posed by cobbles and boulders. Overbreak was typically $5-10 \%$.

In order to check for the presence of gravel lenses, every tenth pile was initially constructed and the arisings were closely monitored. No gravel deposits were encountered either in the pile bores or in the subsequent bulk excavation.

\subsection{Risk and monitoring}

A $600 \mathrm{~mm}$ diameter water main was located $2 \mathrm{~m}$ behind the retaining wall (see Figure 6) and damage to this posed the most considerable risk should excessive movements be recorded. In addition, a high-level access road is located behind the retaining wall (Figure 6). Surfacing to this was not completed until after basement construction so the associated risk was not significant. Early-stage movements were observed carefully. Recorded pile deflections at the two inclinometers during the construction stage were approximately $13 \mathrm{~mm}$ (at B001 where the final cantilever height is $6.3 \mathrm{~m}$ ) and $7.5 \mathrm{~mm}$ (at B002 where the final cantilever height is $4.4 \mathrm{~m}$ ), see Figures 6 and 7 (a). These values were significantly less than both the design stage predictions and the $25 \mathrm{~mm}$ 'trigger' level. Subsequently these values built up gradually, presumably in response to the gradual dissipation of the induced pore water suctions. After construction of the basement slab these deflections have increased slightly and 6 years after beginning of excavation they had increased to a maximum of about $21 \mathrm{~mm}$, a value significantly less than the $45 \mathrm{~mm}$ originally predicted. There has been no recorded movement between years five and six since commencement of monitoring.

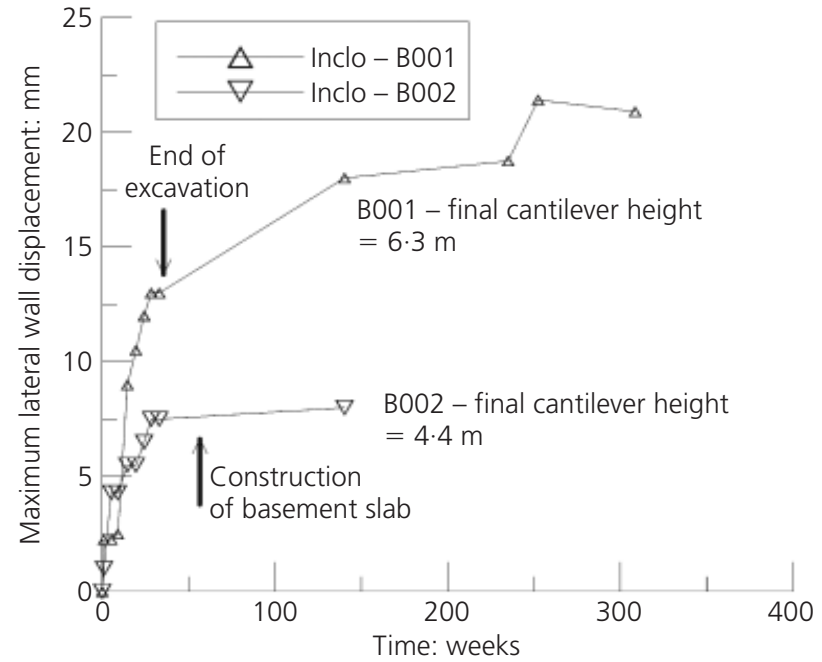

(a)

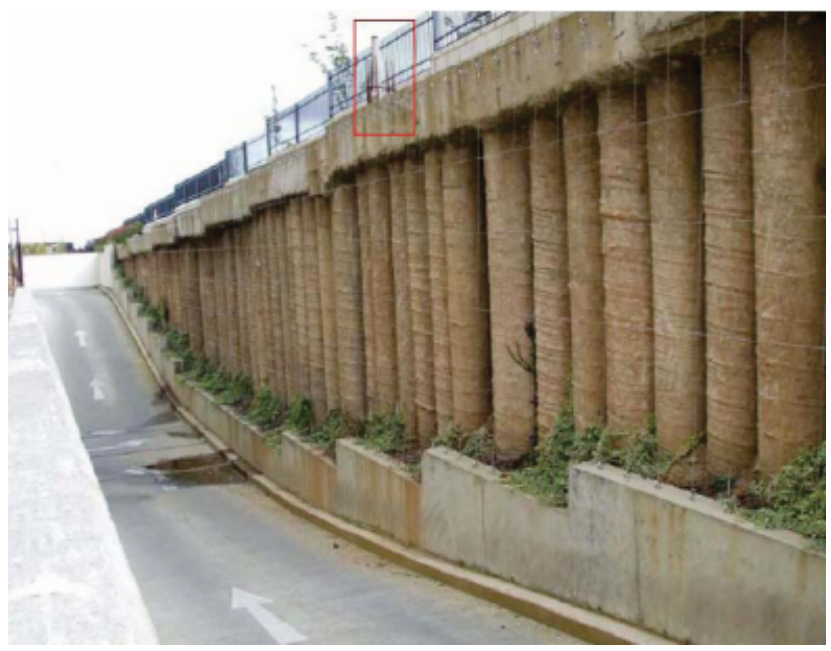

(b)

Figure 7. Ballycullen Road: (a) retaining wall lateral wall movements with time; (b) image of completed wall with variable height cantilever ( $=6.3 \mathrm{~m}$ at inclinometer B001 noted)

No significant water ingress was noted during construction and the contingency measures described above did not have to be implemented.

\subsection{Comment}

A photograph of the completed structure, some 5 years after construction, is shown in Figure 7(b). It can be seen that despite the relatively high cantilever the structure has behaved well and the resulting deflections have been within serviceable limits. This case history confirms the feasibility of using cantilever walls in $\mathrm{DBC}$ in long-term conditions, once design, construction and performance criteria (including contingency measures) are established before construction. Those parties who carry any residual risk, such as contractor, employer or designer, also need to be clearly identified. 


\section{Results for deep excavation - Dublin Port Tunnel northern cut and cover}

\subsection{Scheme}

The Dublin Port Tunnel (DPT) provides a link from the motorway system north of Dublin to the port area (Figure 1). A central section comprising twin bored tunnels was driven by tunnel boring machines launched from a central large-diameter shaft, see Cabarkapa et al. (2003). Shallower sections of the tunnels at either end, where the invert level is less than about $25 \mathrm{~m}$ below ground level, were constructed using cut-and-cover methods. The sides of the cut were generally supported by propped diaphragm walls or bored pile walls. At the northern section of the works an approximate $300 \mathrm{~m}$ length of the tunnel was constructed, in competent glacial tills, within propped diaphragm walls. The diaphragm wall was $1.2 \mathrm{~m}$ thick and was constructed using conventional techniques within $7 \mathrm{~m}$ long bentonite supported panels using rope-mounted clam shell grabs. Data were obtained from 13 inclinometers along this section. At three of these locations the wall was supported by a single high-level tubular steel prop and at the remaining locations two props were used, see Figure 8.

\subsection{Movement monitoring}

Details of the scheme together with the results of some site investigation are shown in Figure 9. For all 13 locations there was an initial excavation during which the diaphragm wall was acting as a cantilever. The retained height in the cantilever mode varied between $3 \mathrm{~m}$ and $7 \mathrm{~m}$ with an average of $5.5 \mathrm{~m}$. Movements recorded by inclinometer varied between 0 and $3.2 \mathrm{~mm}$ with an average of about $1.4 \mathrm{~mm}$.

For the three single prop sections the retained height was either $12 \mathrm{~m}$ or $13 \mathrm{~m}$ and the maximum lateral movement varied between $2 \mathrm{~mm}$ and $4.5 \mathrm{~mm}$. An example for DP8, which is characteristic of the single prop sections, is shown on Figure 9. Of the $4.5 \mathrm{~mm}$ maximum movement, approximately $0.5 \mathrm{~mm}$ occurred during the cantilever stage. Subsequently, during the 3 month period while excavation took place to formation level, the wall moved outwards below the prop to give the curved profile observed.

For the nine double propped cases the retained height varied between $14 \mathrm{~m}$ and $17.5 \mathrm{~m}$ and the resulting maximum lateral movement varied between $2.2 \mathrm{~mm}$ and $8.5 \mathrm{~mm}$ with an average of about $5.3 \mathrm{~mm}$. The behaviour of inclinometer DP36 is characteristic of the double propped sections and its profile at maximum excavation depth, some 50 days after insertion of the upper prop, is shown in Figure 9. The deflected shape is typical for these sections and shows that the wall panels rotate about the upper prop despite the presence of the lower prop (and later the concrete base). Subsequently the upper props take the majority of the load.

\subsection{Prop loads}

At the northern cut-and-cover section 68 steel props were used to support the diaphragm walls. These were mostly of $1220 \mathrm{~mm}$
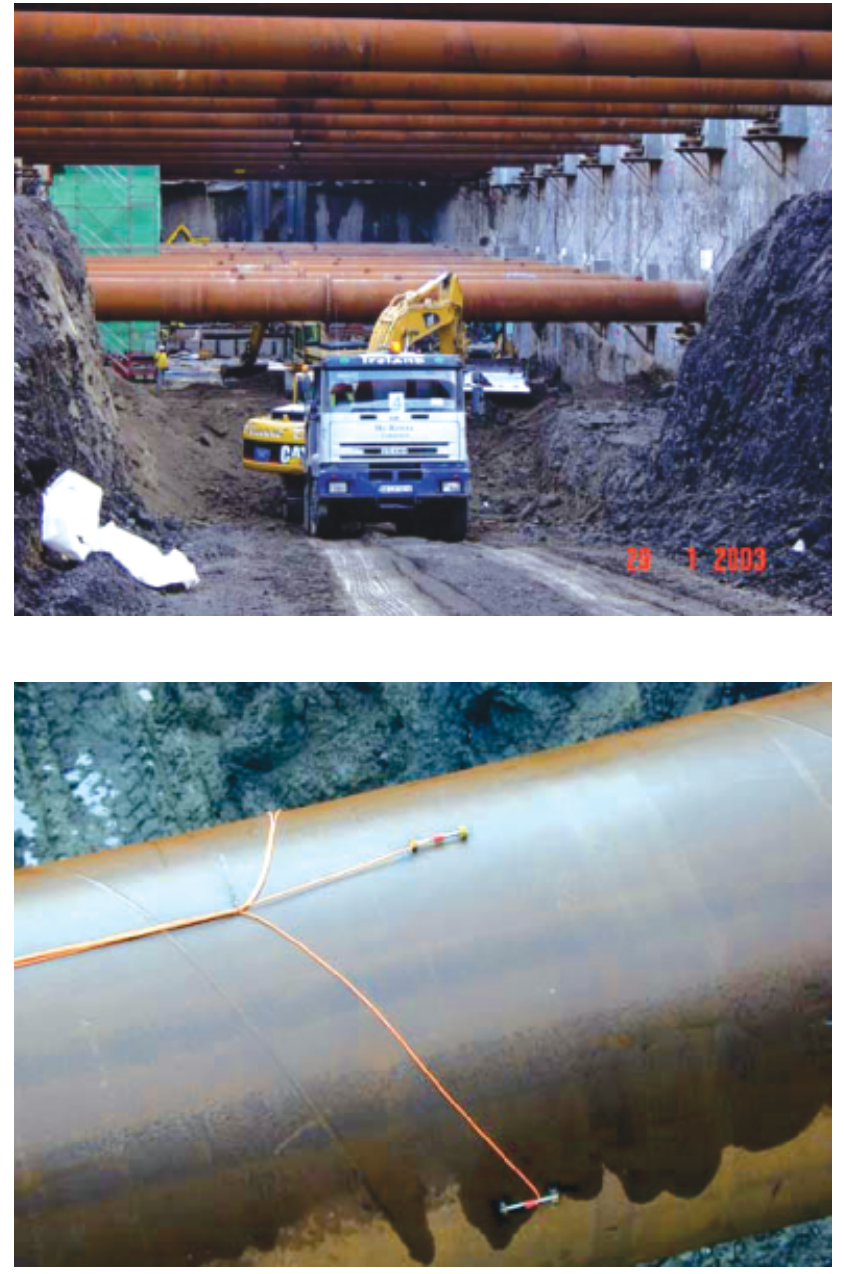

Figure 8. Photograph of Dublin Port Tunnel northern cut and cover works

outside diameter (o.d.) with a $14.2 \mathrm{~mm}$ wall thickness and had previously been used in the offshore industry. Some props of $1520 \mathrm{~mm}$ o.d. and $1620 \mathrm{~mm}$ o.d. were also used. These props spanned approximately $22 \mathrm{~m}$. Props were connected directly to the diaphragm wall by way of reaction pads at $7 \mathrm{~m}$ centres. This gave the advantage of having no waling beam. However, it meant prop positions were fixed and there was the risk of accidental prop removal. The props were not preloaded.

Vibrating wire strain gauges, type Geokon V4-4101, were installed in four upper props at a location where there was also a lower prop. Gauges were attached at the 3, 6, 9 and 12 o'clock positions at both the centre and end of the prop. Although the effect of temperature on prop loads is known to be very significant, see for example Batten et al. (1999) and Twine and Roscoe (1999), unfortunately no thermistors were fitted with the strain gauges and hence temperature correction of loads measured cannot be made. 


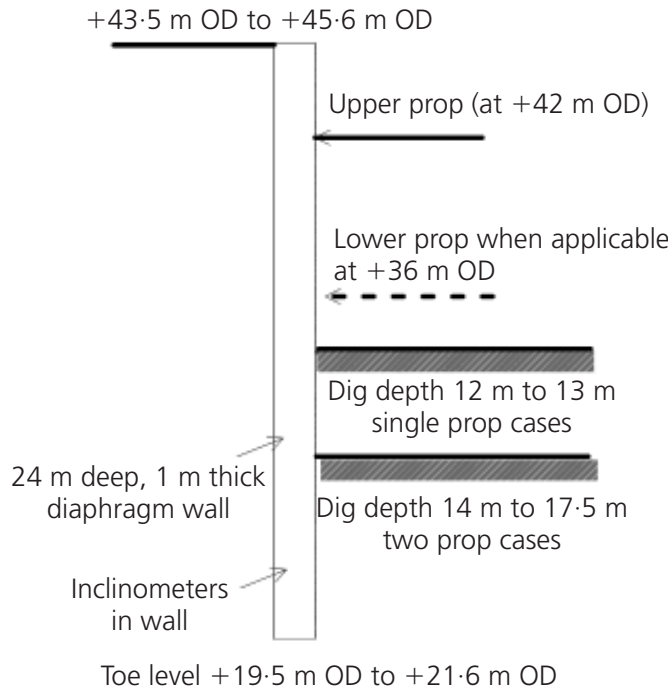

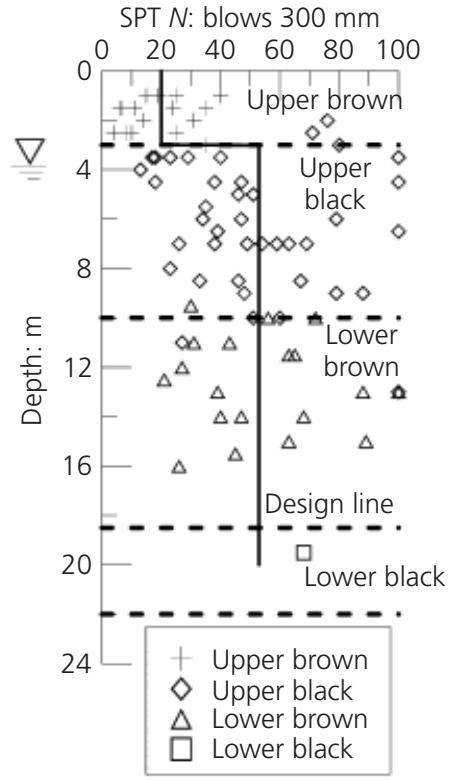

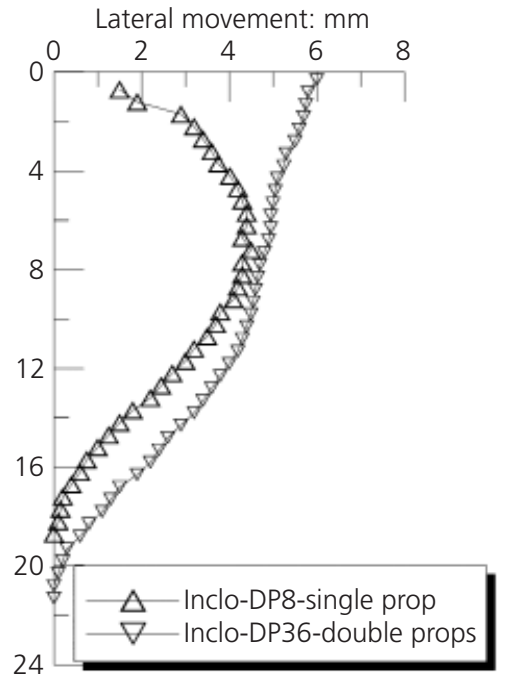

Figure 9. DPT northern cut and cover road: retaining wall layout, ground conditions and lateral wall movements

Measured prop loads for three typical props (numbers 50, 60 and 66, which were respectively $1220 \mathrm{~mm}, 1520 \mathrm{~mm}$ and $1620 \mathrm{~mm}$ o.d.) are shown in Figure 10(a). It can be seen that much of the prop load occurs during excavation to formation level. This is followed by a gradually increasing prop load, which develops presumably in response to the gradual dissipation of excavationinduced depressed pore pressures. Maximum measured prop loads are of the order of $1200 \mathrm{kN}$, which are significantly less than the allowable axial compressive load to prevent buckling (equal to $2800 \mathrm{kN}$ for prop 50). Bending moments at the centre and near the end of prop 66, about the $x-x$ and $y-y$ axes, are shown on Figure 10(b). Not surprisingly the $M_{x x}$ values are slightly higher. Although the calculation of moments towards the end of the prop (strain gauges were approximately $2 \mathrm{~m}$ from the reaction pad) is questionable, all the values are modest and are consistent with the simply supported self-weight bending moment of about $350 \mathrm{kN} \mathrm{m}$.

Measured prop loads are significantly less than those that would be predicted by a beam-spring type program. For example, using the conventional design approach, Oasys-Frew ${ }^{\circledR}$ predicts prop loads in the range $3000-4200 \mathrm{kN}$ for undrained and effective stress based soil parameters respectively. These parameters were obtained from Long and Menkiti (2007a, 2007b) and are summarised in Table 1.

\subsection{Comment}

Despite the very significant depth of the excavation, once again measured movements were modest. Prop forces and bending moments were also lower than expected. Back-analysis of the data presented using a coupled consolidation finite-element analy- sis would be very useful. However, the constitutive model for the DBC needs to be carefully chosen so that it can capture the unique characteristics of the material, in particular the high strength and stiffness and the rapid onset of dilation during shear.

\section{Results overview}

\subsection{Propped walls}

A database, comprising 30 case histories for propped walls in competent glacial deposits, is reproduced in Table 2. This table is an updated version of that originally given by Looby and Long (2007). A plot of maximum measured lateral movement $\left(\delta_{\mathrm{h}}\right)$ against retained height $(H)$ is shown on Figure 11(a). Except for the $11 \mathrm{~m}$ deep excavations at Mespil Road and Tallaght, all $\delta_{\mathrm{h}}$ values are less than about $10 \mathrm{~mm}$. Values less than $10 \mathrm{~mm}$ include the very deep Westgate $(14 \mathrm{~m})$ and Dublin Port Tunnel $(12 \mathrm{~m}$ to $25 \mathrm{~m}$ ) excavations. There does appear to be some weak tendency for an increase in $\delta_{\mathrm{h}}$ with $H$. The average $\delta_{\mathrm{h}}$ is $6.3 \mathrm{~mm}$.

Also shown on Figure 11(a) are lines representing normalised movement $\left(\delta_{\mathrm{h}} / H\right)$ of $0 \cdot 18 \%$ and $0 \cdot 4 \%$. The former relationship was obtained by Long (2001) for an average of 169 case histories worldwide where there was stiff soil at dredge level. The behaviour of the Dublin projects is significantly stiffer than the worldwide average, with an average $\delta_{\mathrm{h}} / H$ of 0.08 . The $0.4 \%$ line represents a typical design value as recommended by Gaba et al. (2003) in Ciria report C580 and clearly this relationship is very conservative for the Dublin cases.

The data shown in Figure 11(a) take no account of the retaining wall type, its stiffness or the prop/anchor configuration. In order 


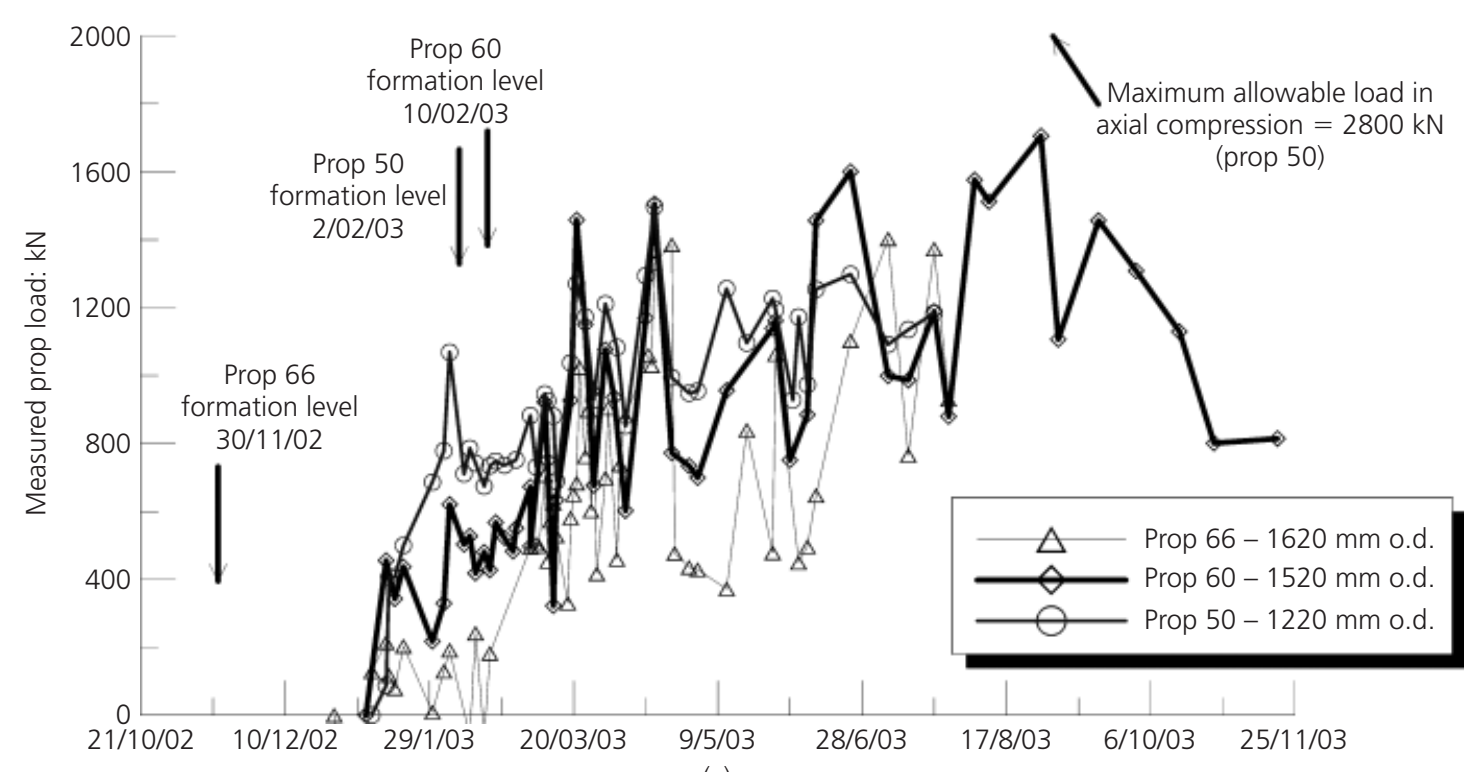

(a)

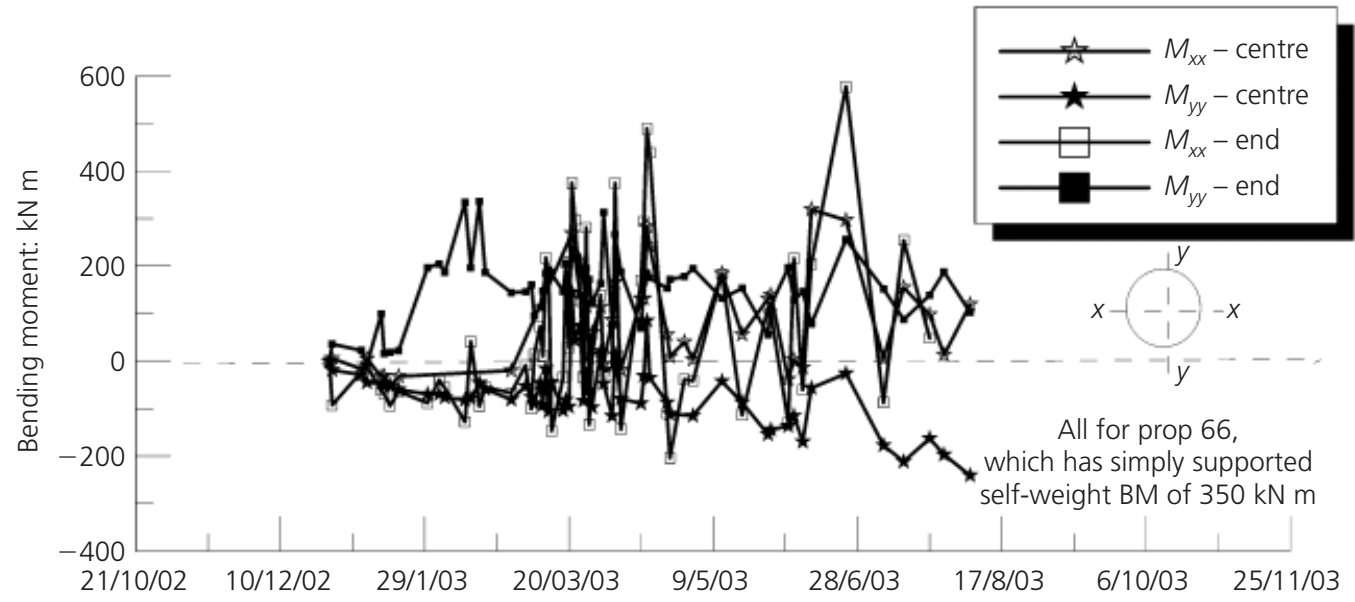

(b)

Figure 10. Dublin Port Tunnel - northern cut and cover:

(a) measured prop loads; (b) bending moment in prop 66

to attempt to include these factors, the data are replotted in Figure 11(b) in the normalised form of $\delta_{\mathrm{h}} / H$ against Clough et al. (1989) system stiffness. This is defined as

1. System stiffness $=\frac{E I}{\gamma_{w} s^{4}}$

where EI is wall stiffness, $\gamma_{\mathrm{w}}$ is unit weight of water (required to make expression unit-less) and $s$ is support spacing.

Lateral movements appear to be independent of stiffness. This suggests that a more flexible (and hence a more economic) wall may perform adequately in many cases.

\subsection{Cantilever walls}

Cantilever walls form ideal temporary or permanent works. The site remains free of internal props or struts allowing construction to continue without obstacles. In particular, perimeter works such as drainage can proceed without hindrance. Difficulties associated with ground anchorages, such as obtaining wayleaves or proof testing, are also avoided. Soil mechanics textbooks suggest cantilever walls are only suitable for modest excavations up to about $4.5 \mathrm{~m}$ retained height. However, throughout the world and more recently in Ireland cantilever walls have been used to retain excavations significantly greater than $4.5 \mathrm{~m}$. A summary of Dublin case histories is given in Table 3. Relatively high cantilever walls have been used for some time and more recently cantilever walls of $7.5 \mathrm{~m}$ or so are being used regularly (e.g. that for Ballycullen Road described above). 


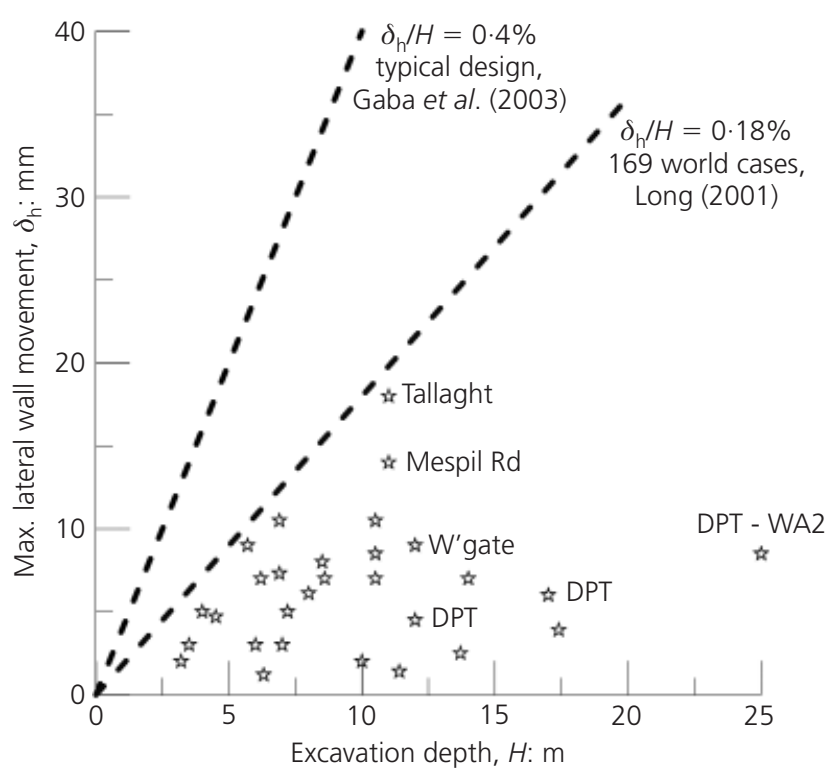

(a)

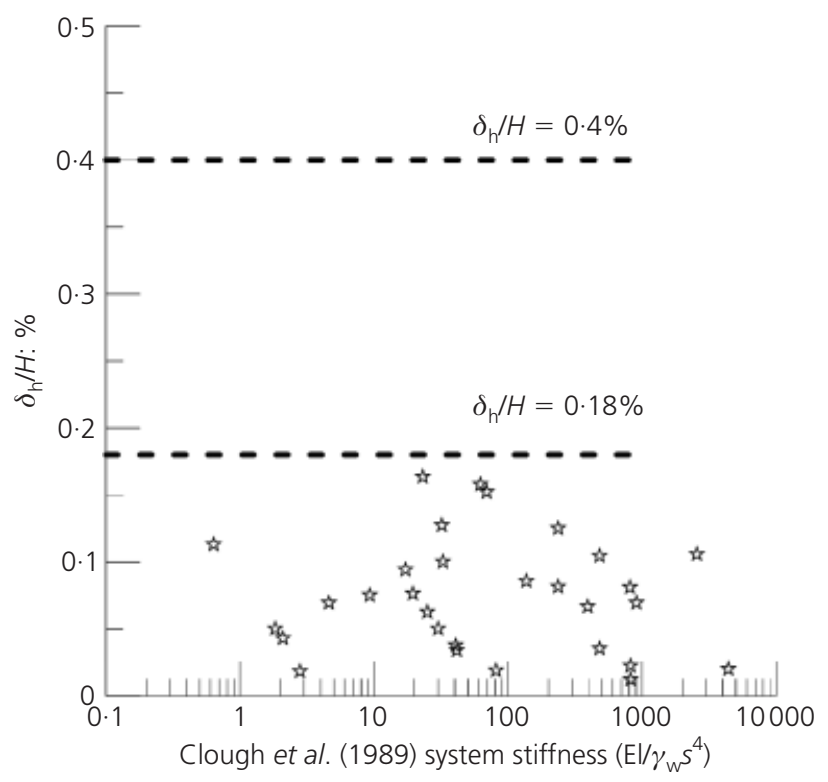

(b)

Figure 11. Behaviour of propped walls: (a) maximum lateral movement plotted against excavation depth; (b) normalised maximum movement plotted against system stiffness

Plots of $\delta_{\mathrm{h}}$ against $H$ and $\delta_{\mathrm{h}} / H$ against system stiffness Clough et al. (1989) are shown on Figures 12(a) and 12(b) respectively. In each case the best-fit trend line from the worldwide database of cantilever walls, from Long (2001), is also shown.

The Dublin walls have performed very well with values falling in general well below the trend lines. Average $\delta_{\mathrm{h}}$ and $\delta_{\mathrm{h}} / H$ values are $6.5 \mathrm{~mm}$ and $0.13 \%$ respectively. Here there is clear dependence on excavation depth and system stiffness, with movements increasing with the former and decreasing with the latter. Irish

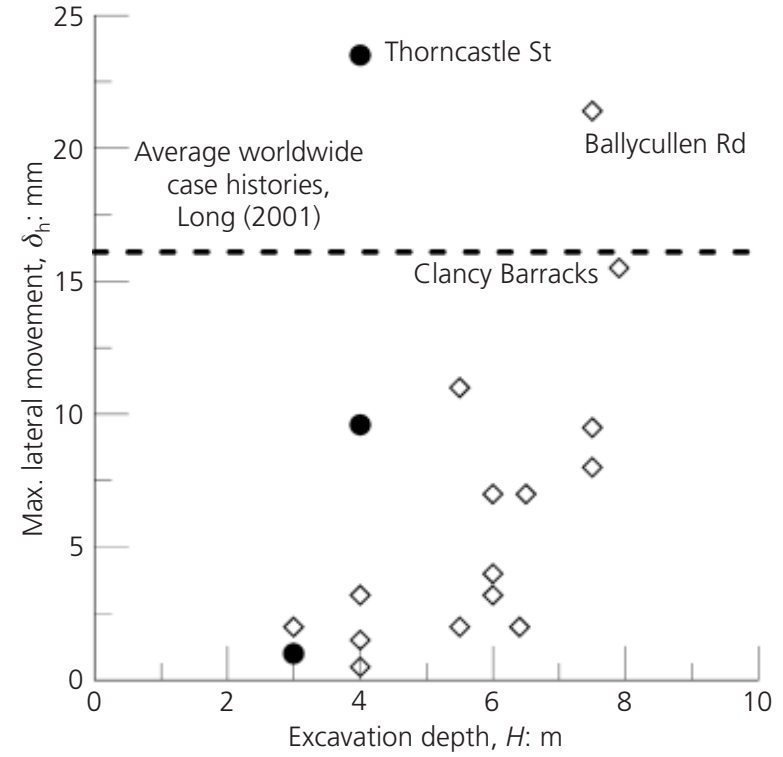

(a)

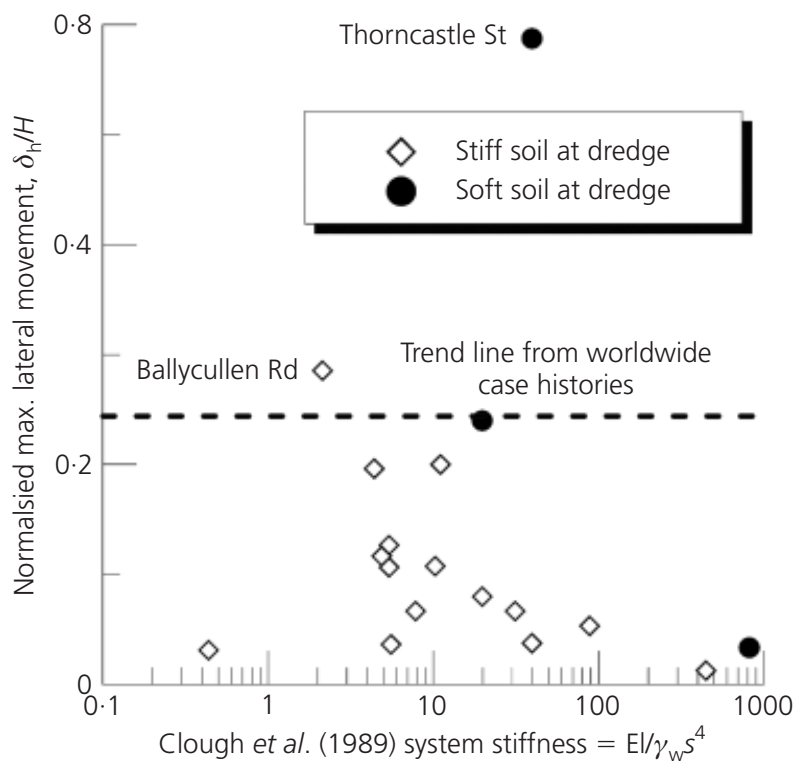

(b)

Figure 12. Behaviour of cantilever walls: (a) maximum lateral movement plotted against excavation depth; (b) normalised maximum movement plotted against system stiffness

practice seems to be conservative and perhaps even more conservative than that worldwide. Based on these data it seems there is scope for the use of higher cantilever walls, at least for temporary works purposes.

\subsection{Behaviour of cantilever walls with time}

The data presented above omit one very important factor, namely how does the lateral movement vary with time. This has important implications as to whether these walls can be used for permanent work as well as temporary works and also in the 


\begin{tabular}{|c|c|c|c|c|c|c|}
\hline $\begin{array}{l}\text { Case } \\
\text { history }\end{array}$ & Location & Soil at dredge lev. & Soil strength, $s_{u}: \mathrm{kPa}$ & $H: \mathrm{m}$ & $h: m$ & $B: \mathrm{m}$ \\
\hline DBC-P1 & Clarendon St car park & DBC & $N=50+$ & $6 \cdot 2$ & 1 & 50 \\
\hline DBC-P2 & M\&S Grafton St & DBC & $N=50+$ & $7 \cdot 2$ & 3 & 30 \\
\hline DBC-P3 & $\begin{array}{l}\text { Dáil Eireann (Leinster } \\
\text { House) }\end{array}$ & DBC & $N=50-100$ & 6 & 0 & 40 \\
\hline DBC-P4 & Hilton Hotel, College St & $\begin{array}{l}\text { Gravel/DBC over wth } \\
\text { rock }\end{array}$ & $N=50+$ & $6 \cdot 3$ & 4 & 40 \\
\hline DBC-P5 & ESAT, Grand Canal & DBC & & 4 & 2 & 30 \\
\hline DBC-P6 & TCD Library - Lecky & Gravel over DBC & $N=30-100$ & $7 \cdot 2$ & 0 & 30 \\
\hline DBC-P7 & TCD Library - Nassau & Gravel over DBC & $N=30-100$ & 8.6 & 0 & 50 \\
\hline DBC-P8 & Ely Place & DBC & $N=47-100$ & 3.5 & 0 & 35 \\
\hline DBC-P9 & Harcourt St & Gravel over DBC & $N=28-100$ & 4.5 & 0 & 35 \\
\hline DBC-P10 & Balbriggan & Gravel over stiff clay & Med. dense/stiff & $5 \cdot 7$ & 2.5 & 41 \\
\hline DBC-P11 & Westgate & Gravel over DBC & $N=20-100$ & 14 & 2 & 125 \\
\hline DBC-P12 & Tallaght Centre & DBC & $N=20-100$ & 11 & 1.5 & 80 \\
\hline DBC-P13 & TCD - Sports Centre & Gravel over DBC & $N=30-100$ & 6.9 & 1 & 30 \\
\hline DBC-P14 & TCD - Crann Building & Gravel over DBC & $N=30-100$ & 6.9 & 1 & 30 \\
\hline DBC-P15 & DPT Northern C\&C - DP8 & DBC & $N=30-100$ & 12 & 1 & 22 \\
\hline DBC-P16 & DPT Northern C\&C - DP36 & $5 \mathrm{DBC}$ & $N=30-100$ & 17 & 1 & 22 \\
\hline DBC-P17 & DPT - Shaft WA2 & DBC & $N=30-100$ & 25 & 1 & 28.3 \\
\hline DBC-P18 & Mespil Road & DBC & $N=30-100$ & 11 & 2 & 65 \\
\hline DBC-P19 & TCD - Biosciences (3) & Gravel over DBC & $N=30-100$ & $10 \cdot 5$ & 4 & 38 \\
\hline DBC-P20 & TCD - Biosciences (2) & Gravel over DBC & $N=30-100$ & $10 \cdot 5$ & 4 & 105 \\
\hline DBC-P21 & TCD - Biosciences (1) & Gravel over DBC & $N=30-100$ & $10 \cdot 5$ & 4 & 105 \\
\hline DBC-P22 & Monte Vetro - Quay Wall & $\begin{array}{l}\text { Gravel over DBC over } \\
\text { rock }\end{array}$ & $N=40-80$ & $13 \cdot 7$ & & 66 \\
\hline DBC-P23 & Monte Vetro - CIE Wall & $\begin{array}{l}\text { MG, gravel over DBC } \\
\text { over rock }\end{array}$ & DBC $40-80$ & $17 \cdot 4$ & 8 & $12-66$ \\
\hline DBC-P24 & $\begin{array}{l}\text { Monte Vetro - Barrow St } \\
\text { Wall }\end{array}$ & $\begin{array}{l}\text { Alluvium, gravel over } \\
\text { DBC over rock }\end{array}$ & DBC $40-80$ & $11 \cdot 4$ & 4 & 66 \\
\hline DBC-P25 & H.J. Lyons Pearse St & Gravel over UBrBC & $N=18-50 t$ & 12 & 3 & $20-50$ \\
\hline DBC-P26 & Cherrywood Block F & DBC & $N=20-50+$ & 8.5 & 1 & 32 \\
\hline DBC-P27 & Mater Hospital - anchored & DBC over gravel & $N=15-50+$ & 8 & 0.6 & 50 \\
\hline DBC-P28 & Lidl, Rathmines & DBC over rock at $5 \mathrm{~m}$ & $N=30-100$ & 7 & 1 & 20 \\
\hline DBC-P29 & Burlington Road & $\begin{array}{l}\text { DBC over rock at dig } \\
\text { base }\end{array}$ & $N=30-100$ & 10 & 2 & $?$ \\
\hline DBC-P30 & Terrenure & Fill, UBrBC, UBkBC & $20-50(40)$ & 3.2 & 0.3 & 35 \\
\hline
\end{tabular}




\begin{tabular}{|c|c|c|c|c|c|c|c|}
\hline $\begin{array}{l}\text { Support } \\
\text { configuration }\end{array}$ & $s: m$ & Wall type & Pile dia./spacing/length: m & El: $k N / m^{2}$ & $\delta_{\mathrm{h}}: \mathrm{mm}$ & $\delta_{\mathrm{v}}: \mathrm{mm}$ & Reference \\
\hline Single prop & 5 & Soldier pile & $\begin{array}{l}9 \mathrm{~m} \text { long } 357 \times 171 \times 45 \\
\mathrm{~kg} / \mathrm{m} \cup B \text { at } 6 \mathrm{~m} \text { centres }\end{array}$ & 3895 & 7 & 0 & Long (1997) \\
\hline Single prop & 6 & Sheet piles & Larssen 16W, 7 m long & 58500 & 5 & 2 & Long (1997) \\
\hline Single prop & 6 & Secant & $0 \cdot 6 / 0 \cdot 5 / 9$ & 381700 & 3 & 0 & Brangan (2007) \\
\hline Single prop & $6 \cdot 3$ & Secant & $0 \cdot 9 / 0 \cdot 75 / 6$ & 1254800 & $1 \cdot 2$ & 0 & Long (2002) \\
\hline Single anchor & $3 \cdot 5$ & Secant & $0 \cdot 6 / 0 \cdot 55 / 10$ & 347000 & 5 & $? ?$ & UCD files \\
\hline Two anchors & $3 \cdot 5$ & Secant & $0 \cdot 6 / 0 \cdot 55 / 11$ & 347000 & 7 & $? ?$ & Brangan (2007) \\
\hline Single prop/anchor & $3 \cdot 5$ & Secant & $0.45 / 0 \cdot 3 / 6$ & 201300 & 3 & $? ?$ & Brangan (2007) \\
\hline Single prop & 3 & Secant & $0 \cdot 6 / 0 \cdot 5 / 8 \cdot 5$ & 381700 & $4 \cdot 7$ & $? ?$ & Brangan (2007) \\
\hline Single anchor & $5 \cdot 7$ & Secant & $0.9 /$ hard at $1.5 / 9.5$ & 644126 & 9 & $? ?$ & BLP files \\
\hline Single anchor & 14 & Secant & $0.9 /$ hard at $1.4 / 22$ & 690135 & 7 & $? ?$ & Looby and Long (2007) \\
\hline Single anchor & 6 & Contiguous & $0 \cdot 6 / 0 \cdot 75 / 13$ & 293620 & 18 & ?? & BLP files \\
\hline Single anchor & $5 \cdot 55$ & Secant & $0 \cdot 9 /$ hard at $1 \cdot 5 / 11$ & 644126 & $10 \cdot 5$ & $? ?$ & BLP files \\
\hline Three level anchors & $2 \cdot 25$ & Secant & $0 \cdot 9 /$ hard at $1 \cdot 5 / 11$ & 644126 & $7 \cdot 3$ & $? ?$ & BLP files \\
\hline Two props & $5 \cdot 5$ & Diaphragm & $1 \cdot 2$ thick/24 long & 4320000 & 6 & $? ?$ & Curtis and Doran (2003) \\
\hline Single ring beam & 12 & Diaphragm & 1.5 thick/32.5 long & 8437500 & 8.5 & ?? & Cabarkapa et al. (2003) \\
\hline Single prop & 8 & Secant & $0 \cdot 9 / 0 \cdot 75 / ?$ & 1288250 & 14 & 6 & BLP files \\
\hline Three anchors & 3.6 & Secant & $0.9 / 1.4$ & 644125 & 7 & $2-7$ & ARUP files 2009 \\
\hline Two anchors & 3 & Secant & $0 \cdot 9 / 1 \cdot 4$ & 644125 & 8.5 & $? ?$ & ARUP files 2009 \\
\hline Single anchor & $6 \cdot 7$ & Secant & $0 \cdot 9 / 1 \cdot 4$ & 644125 & $10 \cdot 5$ & $? ?$ & ARUP files 2009 \\
\hline Single prop & 12 & Secant & $0.9 / 1.45$ & 568400 & $2 \cdot 5$ & $? ?$ & ARUP files 2008 \\
\hline Three level anchors & 2.9 & Secant & $0.9 / 1.45$ & 568400 & 3.9 & $? ?$ & ARUP files 2008 \\
\hline Two level anchors & $2 \cdot 9$ & Secant & $0.9 / 1.45$ & 568400 & $1 \cdot 4$ & $? ?$ & ARUP files 2008 \\
\hline Two props & 8 & Secant & $0.75 / 1 \cdot 25$ & 372750 & 9 & $? ?$ & ARUP files 2008 \\
\hline Single anchor & $8 \cdot 5$ & Contiguous & $0 \cdot 9 / 1 \cdot 1 / 14$ & 878355 & 8 & $? ?$ & BLP files \\
\hline Single anchor & $7 \cdot 75$ & Secant & $0.9 /$ hard at $1.4 / 12.5$ & 690135 & $6 \cdot 1$ & & BLP files/ARUP files 2009 \\
\hline Single anchor & 6 & Contiguous & $0 \cdot 3 / 0 \cdot 45$ & 26500 & 3 & $? ?$ & BLP files \\
\hline Single anchor & 2 & Secant & $0.9 /$ hard at $1.4 / 12$ & 690135 & 2 & $? ?$ & BLP files \\
\hline Single raked prop & $3 \cdot 2$ & Sheet piles & Light piles/Heavy trench sheets & ts 25700 & 2 & $? ?$ & Kearon (2009) \\
\hline
\end{tabular}




\begin{tabular}{|c|c|c|c|c|c|c|c|}
\hline $\begin{array}{l}\text { Case } \\
\text { history }\end{array}$ & Location & $\begin{array}{l}\text { Soil at } \\
\text { dredge lev. }\end{array}$ & Soil strength, $s_{u}: \mathrm{kPa}$ & $H: m$ & $h: \mathrm{m}$ & $B: \mathrm{m}$ & $s: m$ \\
\hline & Stiff soil at dredge & & & & & & \\
\hline 1 & Ship St, Dublin & $\mathrm{DBC}$, grav & V. stiff/dense & 3 & 2 & 25 & $4 \cdot 2$ \\
\hline 2 & Intel, Leixlip & $\mathrm{DBC}$ & V. stiff/dense & $6 \cdot 4$ & 0 & 50 & 8.96 \\
\hline 3 & Schoolhouse Lane & $\mathrm{DBC}$ & V. stiff/dense & $5 \cdot 5$ & 0 & 33 & $7 \cdot 7$ \\
\hline 4 & New St & $\mathrm{DBC}$, Imst & $N=66-82$ & $5 \cdot 5$ & 2 & 38 & $7 \cdot 7$ \\
\hline 5 & Cork St & $\mathrm{DBC}$ & $N=55+$ & 6 & $2 \cdot 5$ & 40 & $8 \cdot 4$ \\
\hline 6 & Ballycullen Rd. & $\mathrm{DBC}$ & $N=50-100$ & $7 \cdot 5$ & $1 \cdot 5$ & 30 & $10 \cdot 5$ \\
\hline 7 & DPT Northern C\&C - DP8 & DBC & V. stiff/hard & 4 & 1 & 22 & $5 \cdot 6$ \\
\hline 8 & DPT Northern C\&C - DP36 & DBC & V. stiff/hard & 6 & 1 & 22 & $8 \cdot 4$ \\
\hline 9 & Mater Hospital - cantilever & DBC & $N=35+$ & $6 \cdot 5$ & 0.6 & 50 & $9 \cdot 1$ \\
\hline \multicolumn{8}{|c|}{-1} \\
\hline 11 & Clancy Barracks - cantilever & Fill/silt, dense gravel, DBC & $5-80(42)$ & $7 \cdot 9$ & 4 & 150 & 11.06 \\
\hline 12 & Hammond Lane & Made ground, dense gravel, DBC, Imst. & $20-80(42)$ & 4 & 3 & 40 & $5 \cdot 6$ \\
\hline 13 & Church Street & Fill, dense gravels & $20-80(45)$ & 6 & $4 \cdot 5$ & 30 & $8 \cdot 4$ \\
\hline 15 & Spencer Dock, NCC building & Fill, soft silt, med dense gravel and DBC & Med dense gravel (20) & $7 \cdot 5$ & $7 \cdot 5$ & 75 & $10 \cdot 5$ \\
\hline \multirow[t]{2}{*}{16} & North Wall Quay & Fill, soft silt, dense gravel and DBC & Dense gravel with $N=35+$ & $7 \cdot 5$ & $4 \cdot 5$ & 125 & $10 \cdot 5$ \\
\hline & Soft soil at dredge & & & & & & \\
\hline 17 & Thorncastle & Fill, alluvium, dense gravel, DBC & SPT $N=10$ & 4 & 13 & 30 & $5 \cdot 6$ \\
\hline 18 & DPT Southern C\&C & Complex estuarine & Soft to firm & 3 & 8 & 22 & $4 \cdot 2$ \\
\hline 19 & Portmarnock - Cantilever & Soft sandy silt & $\begin{array}{l}\text { As over with } \mathrm{DBC} 1.5 \mathrm{~m} \text { below, } \\
\mathrm{N}=2-6\end{array}$ & 4 & 6 & 40 & $5 \cdot 6$ \\
\hline
\end{tabular}




\begin{tabular}{|c|c|c|c|c|c|}
\hline Wall type & Pile dia./spacing/length: m & $\mathrm{El}: \mathrm{kN} / \mathrm{m}^{2}$ & $\delta_{\mathrm{h}}: \mathrm{mm}$ & $\delta_{\mathrm{v}}: \mathrm{mm}$ & Reference \\
\hline Secant & $0.6 /$ hard at $1 \cdot 2 / ?$ & 95426 & 2 & $?$ & UCD files \\
\hline Contiguous & $0.35 / 0.6$ to $1 / 9$ & 27600 & 2 & $?$ & Long (1997) \\
\hline Secant & $0 \cdot 6 / 0 \cdot 5 / 8$ & 381700 & 11 & $?$ & BLP files \\
\hline Contiguous & $0 \cdot 6 / 0 \cdot 8 / 9$ & 238550 & 7 & $?$ & BLP files \\
\hline Contiguous & $0 \cdot 6 / 0 \cdot 75 / 14$ & 254470 & $21 \cdot 4$ & $?$ & Looby and Long (2007) \\
\hline Diaphragm & 1.0 thick/24 long & 4320000 & 0.5 & $?$ & Curtis and Doran (2003) \\
\hline Diaphragm & $1 \cdot 0$ thick/24 long & 4320000 & $3 \cdot 2$ & $?$ & Curtis and Doran (2003) \\
\hline Secant & $0.9 /$ hard at $1.4 / 12.8 \mathrm{~m}$ to $14.3 \mathrm{~m}$ & 690135 & 7 & & BLP files in progress - IC 11 or 14 \\
\hline Secant & $0 \cdot 9 / 1 \cdot 5 / 15 \cdot 5$ & 644126 & $15 \cdot 5$ & $?$ & Looby and Long (2010)/Kearon (2009) \\
\hline Secant & $0 \cdot 6 / 0 \cdot 5 / 9 \cdot 5$ & 381700 & $1 \cdot 5$ & $?$ & Brangan $(2007)$ \\
\hline Secant & $0 \cdot 6 / 0 \cdot 5 / 12 \cdot 5$ & 381700 & 4 & $?$ & Looby and Long (2010) \\
\hline Secant & $0 \cdot 6 / 1 / 9 \cdot 5$ & 190850 & $3 \cdot 2$ & $?$ & Looby and Long (2010) \\
\hline Secant & $0 \cdot 9 /$ hard at $1.5 / 15 \cdot 25$ & 644126 & $9 \cdot 5$ & $?$ & Looby and Long (2007) - Inclo4 \\
\hline \multirow[t]{2}{*}{ Secant } & $0 \cdot 9 /$ hard at $1 \cdot 5 / 15 \cdot 5$ & 644126 & 8 & $?$ & BLP files \\
\hline & & & $6 \cdot 52$ & & \\
\hline Secant & $0 \cdot 6 / 0 \cdot 5 / 13$ & 381700 & $23 \cdot 5$ & $?$ & Brangan (2007) \\
\hline Diaphragm & 1.0 thick/24 long & 2500000 & 1 & $?$ & Curtis and Doran (2003) \\
\hline Secant & $0 \cdot 6 / 1 \cdot 0 / 7$ & 191000 & $9 \cdot 6$ & $?$ & BLP files - IC 1 \\
\hline
\end{tabular}


temporary case how long is the useful life span. Data from ten sites in competent glacial soils - from Long (2002), Curtis and Doran (2003), Looby and Long (2007), Kearon (2009), Looby and Long (2010) and other new data - are shown on Figure 13(a). In most of the projects, after a relatively short time, the retaining wall was incorporated into the permanent works, meaning it was no longer acting as a cantilever. Therefore the data for the permanent wall at Ballycullen Road are of particular interest as they span a period of some six years. In Figure 13(b) the data for the first 50 weeks are shown in more detail.

It can be seen that in all cases there is a gradual development of movement increasing with time. In particular after the first 50 weeks the rate of movement decreases significantly. This behaviour is probably due to the gradual dissipation of depressed pore

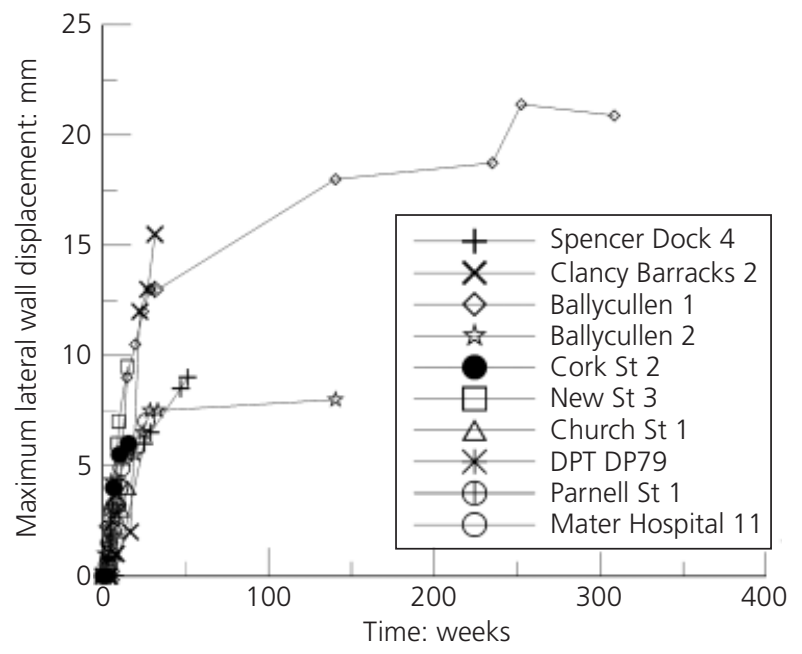

(a)

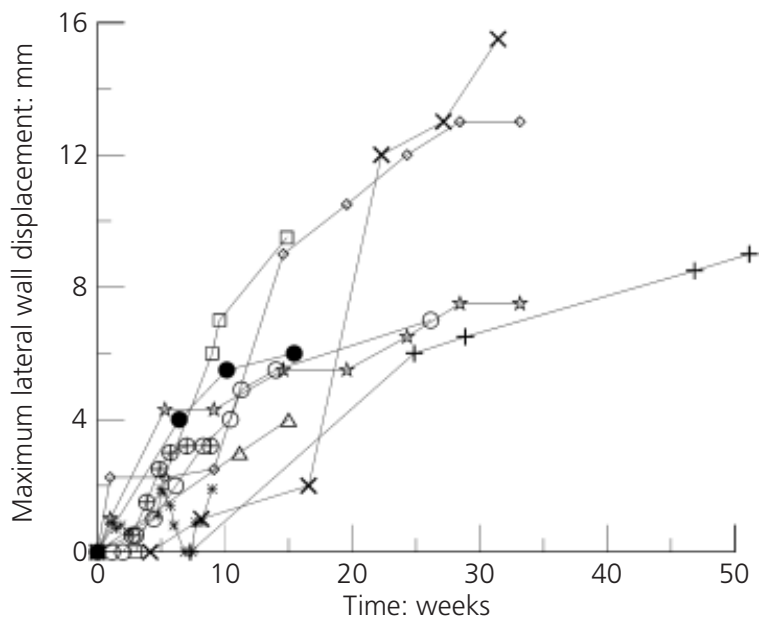

(b)

Figure 13. Behaviour of cantilever walls with time: (a) all data; (b) detail of first 50 weeks pressures (or even suctions). This will be discussed in the following sections.

\section{Discussion}

The reasons for the very stiff behaviour of the retaining walls in Dublin Boulder Clay are complex but can be attributed to a combination of the following factors.

- Excavation-induced depressed pore pressures (or even suctions), as has been demonstrated previously for open cuts in the material by Long et al. (2003, 2004), result in increased effective stress and hence stability.

- The low permeability of the material $\left(10^{-10} \mathrm{~m} / \mathrm{s}\right.$ or less $)$ means that the dissipation of the depressed pore pressures takes a long time.

- The material has extremely high stiffness. For example Long and Menkiti (2007b) report that it is about six to eight times stiffer than London Clay and about five times stiffer than Cowden till.

It is also very strong with the UBkBC having undrained shear strength in triaxial compression in excess of $350 \mathrm{kPa}$ (i.e. close to the strength of a weak rock).

A possible approach for the design of temporary retaining structures in the material may be in the use of undrained parameters in conjunction with the observational approach. The benefits of using undrained parameters are not so much that pile sizes will be reduced, but that more cost-effective overall solutions can be employed, for example reduced propping requirements. This approach should only be considered where the predicted deflections using an effective stress approach would be within defect limits to prevent the possibility of damage, economic loss or unsafe situations. The risk associated with the decision should be clearly assessed in terms of understanding of the site geology (e.g. the possibility of encountering gravel lenses), type and condition of structures to the rear of the pile wall and the quality of monitoring procedures and contingency measures put in place.

It seems there is scope for the greater use of cantilever walls and also greater retained heights at least for temporary works purposes. Possible compromise solutions should also be considered. An example is the $7 \mathrm{~m}$ deep excavation in Dublin Port, described by Adekunte et al. (2010), where the $600 \mathrm{~mm}$ diameter contiguous piled wall was supported by a $2.5 \mathrm{~m}$ wide concrete counterweight structure behind the wall.

It must also be emphasised that an effective stress design approach is always needed for the ultimate limit state analysis in permanent works as the suctions will eventually dissipate.

\section{Conclusion}

(a) Comprehensive case history data confirm that retaining wall behaviour in Dublin Boulder Clay is extremely stiff. This applies to propped excavations up to $25 \mathrm{~m}$ deep and to cantilever walls $7.5 \mathrm{~m}$ high. 
(b) The reasons for this stiff behaviour lie in the low permeability and high strength and stiffness of the material and the resulting very slow dissipation of depressed excavation-induced pore pressures.

(c) It appears that the current approach for serviceability limit state calculations, which usually involves beam-spring type computer programs, is clearly conservative for the parameters used.

(d) In addition to deflections, prop loads are significantly overpredicted and there would seem to be scope for more efficient design of the wall support systems.

(e) For temporary works, the use of undrained parameters in conjunction with the observational approach may be considered for reducing predicted deflections to simplify the construction sequence and reduce costs.

$(f)$ Measurement of pore water pressure at the rear of walls should be carried out so as to confirm the above observations and improve the confidence of future engineers in designing such structures.

\section{Acknowledgements}

Some of the data used in this paper were kindly provided by $\mathrm{Mr}$ Tony O'Dowd, PJ Edwards and Co., Mr Pat Fox, Murphy International Ltd and $\mathrm{Mr}$ Douglas Cook, FK Lowry Piling Contractors; their co-operation is gratefully acknowledged.

\section{REFERENCES}

Adekunte A, O'Hara P and Denanny A (2010) Novel methods of restraining retaining walls. Proceedings of the 13th International Conference on Piling and Deep Foundations, Hollywoood, CA, USA, paper 172.

Batten M, Powrie W, Boorman R, Yu H-T and Leiper Q (1999) Use of vibrating wire strain gauges to measure loads in tubular steel props supporting deep retaining walls. Proceedings of the Institution of Civil Engineers Geotechnical Engineering 137(1): 3-13.

Brangan C (2007) Retaining Walls in Dublin Boulder Clay. PhD thesis, Civil Engineering Department, University College Dublin, Ireland.

BSI (1994) BS 8002: Code of practice for earth retaining structures. BSI, London, UK

Burland JB, Broms BB and De Mello V (1977) Behaviour of foundations and structures. Proceedings of the IXth International Conference on Soil Mechanics and Foundation Engineering, Tokyo, Japan, vol. 2, 495-546.

Cabarkapa Z, Milligan GWE, Menkiti CO, Murphy J and Potts DM (2003) Design and performance of a large diameter shaft in Dublin Boulder Clay. Proceedings of the British Geotechnical Association International Conference on Foundations, Dundee, Scotland. Thomas Telford, London, UK 175-185.

Clough GW and O'Rourke TD (1990) Construction induced movements of in situ walls. Proceedings of the ASCE
Conference on Design and Performance of Earth Retaining Structures, Cornell, USA. ASCE, Reston, VA, USA, Publication No. 25 vol. 2, pp. 439-470.

Clough GW, Smith EM and Sweeney BP (1989) Movement control of excavation support systems by iterative design. Proceedings of the ASCE Foundation Engineering: Current Principles and Practices. ASCE, Reston, VA, USA, vol. 2, pp. 869-884.

Curtis P and Doran J (2003) Retaining Wall Behaviour at the Dublin Port Tunnel. BE Project Civil Engineering Department, University College Dublin, Ireland.

Gaba AR, Simpson B, Powrie W and Beadman DR (2003) Embedded Retaining Walls - Guidance for Economic Design. Ciria, London, UK, Report No. C580.

Kearon B (2009) The Use of LiDAR to Monitor Retaining Wall Movements and the Engineering Geology of the Dublin Docklands. Civil Engineering Department, Univeristy College Dublin, Ireland.

Long MM (1997) Design and Construction of Deep Basements in Dublin, Ireland. Proceedings of the 14th International Conference on Soil Mechanics and Foundation Engineering, Hamburg, Germany. Balkema Rotterdam, the Netherlands, vol. 2, pp. 1377-1380.

Long M (2001) A database for retaining wall and ground movements due to deep excavations. Journal of Geotechnical and Geoenvironmental Engineering, ASCE 127(3): 203224.

Long M (2002) Observations of ground and structure movements during site re-development in Dublin. Proceedings of the Institution of Civil Engineers - Geotechnical Engineering 155(4): 229-242.

Long M and Menkiti CO (2007a) Characterisation and engineering properties of Dublin Boulder clay. Proceedings of the 2nd International Workshop on Characterisation and Engineering Properties of Natural Soils - Natural Soils 2006 (Tan TS et al. (eds)). Taylor and Francis, London, UK, vol. 3, pp. 2003-2045.

Long M and Menkiti CO (2007b) Geotechnical properties of Dublin Boulder Clay. Géotechnique 57(7): 595-611.

Long M, Menkiti CO, Kovacevic N et al. (2003) An observational approach to the design of steep sided excavations in Dublin glacial till. Proceedings of Underground Construction 2003 UC2003, ExCeL. London, Hemming-Group Ltd, pp. 443-454.

Long M, Menkiti CO and Follett B (2004) Some experience in measuring pore water suctions in Dublin glacial till. Geotechnical News/Geotechnical Instrumentation News (GIN) 22(3): 21-27.

Long M, Brangan C, Menkiti C and Looby M (2012a) Retaining wall behaviour in Dublin estuarine deposits, Ireland. Proceedings of the Institution of Civil Engineers Geotechnical Engineering 165(6), http://dx.doi.org/10.1680/ geng.10.00037.

Long M, Daynes PJ, Donohhue S and Looby M (2012b) Retaining wall behaviour in Dublin's fluvio-glacial gravel, Ireland. Proceedings of the Institution of Civil Engineers - 
Geotechnical Engineering 165(5), http://dx.doi.org/10.1680/ geng.9.00099.

Looby M and Long M (2007) Deep excavations in Dublin recent developments. Transactions of Engineers - Ireland 131: $1-15$.

Looby M and Long M (2010) Behaviour of cantilever retaining walls in Dublin soils. Proceedings of the DFI/EFFC 11th

International Conference: Geotechnical Challenges in Urban Regeneration, ExCeL, London, paper 217.

Nicholson DP, Tse CM and Penny C (1999) The Observational
Method in Ground Engineering: Principles and Practices. Ciria, London, UK, Report No. 185.

Skipper J, Follett B, Menkiti C, Long M and Clark-Hughes J (2005) The engineering geology and characterisation of Dublin Boulder Clay. Quarterly Journal of Engineering Geology and Hydrogeology (QJEGH) 38(2): 171187.

Twine D and Roscoe H (1999) Temporary Propping of Deep Excavations - Guidance on Design. CIRIA, London, UK, Report No. C517.

\section{WHAT DO YOU THINK?}

To discuss this paper, please email up to 500 words to the editor at journals@ice.org.uk. Your contribution will be forwarded to the author(s) for a reply and, if considered appropriate by the editorial panel, will be published as a discussion in a future issue of the journal.

Proceedings journals rely entirely on contributions sent in by civil engineering professionals, academics and students. Papers should be 2000-5000 words long (briefing papers should be 1000-2000 words long), with adequate illustrations and references. You can submit your paper online via www.icevirtuallibrary.com/content/journals, where you will also find detailed author guidelines. 